Description and analysis of the vascular flora of the Cataraqui Marsh area 
The map on the cover has dots representing

Agriculture Canada rescarch establishments. 


\section{Description and analysis of the vascular flora of the Cataraqui Marsh area}

PAUL M. CATLING

Biosystematics Research Institute

Ottawa, Ontario

Research Branch

Agriculture Canada

1985 
Copies of the publication are available from:

Dr. Paul M. Catling

Biosistematics Research Institute

Research Branch, Agriculture Canada

Wim. Saunders Building

Central Experimental Farm

Ottawa, Ontario

KIA 0C6

Produced by Research Program Service

(c) Minister of Supply and Services Canada 1985

Cat. No. A54-8/1985-7E

ISBN 0-662-14382-5 


\section{CONTENTS}

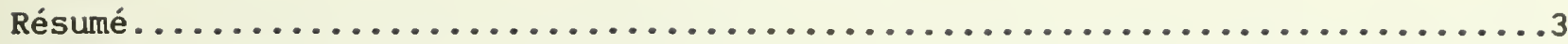

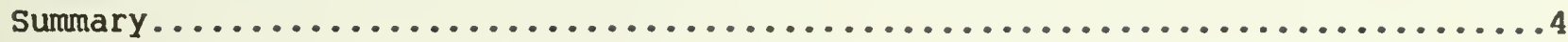

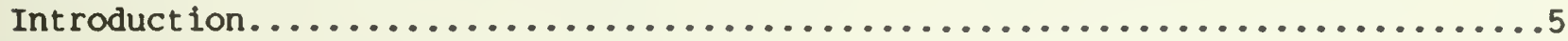

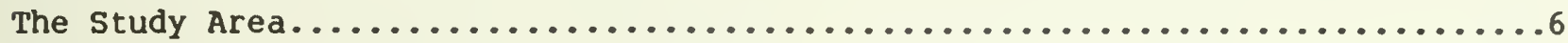

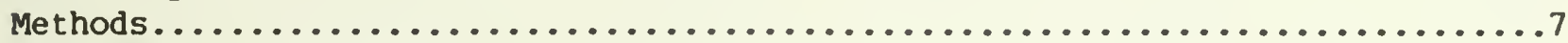

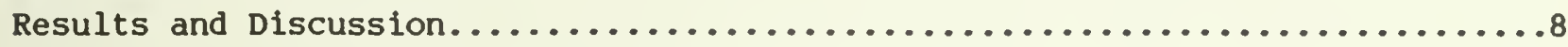

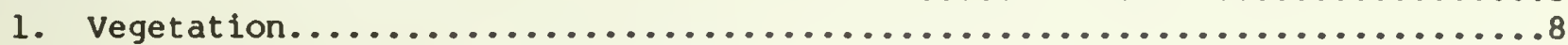

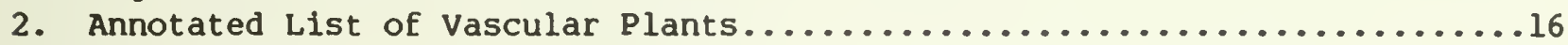

3. Phytogeography........................................... 44

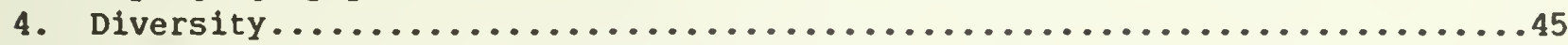

5. Significant species and Communities..........................

6. Significance of the Vegetation to waterfowl and other wildlife $\ldots \ldots \ldots . .47$

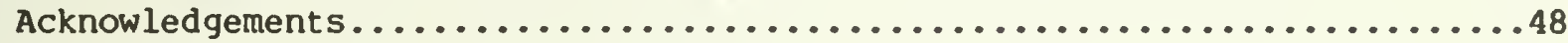

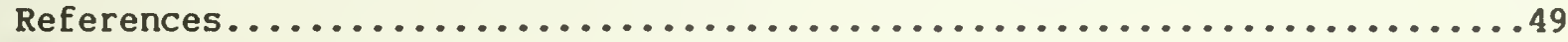

LIST OE TABLES

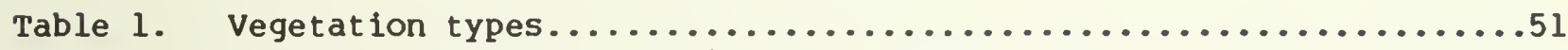

Table 2. Numbers of aquatics in six Great Lakes marshes..............52

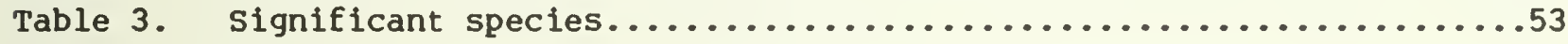

\section{LIST OF FIGURES}

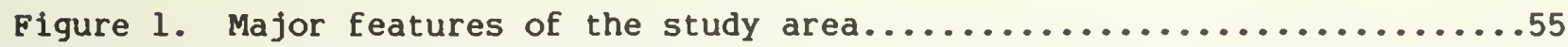

Figure 2. Aerial photograph of the study area......................

Figure 3. Locations of wooded areas $(A) \ldots \ldots \ldots \ldots \ldots \ldots \ldots \ldots \ldots \ldots \ldots . . \ldots \ldots$

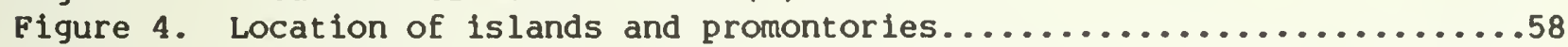

Figure 5. Locations of major areas of thickets (B) and open herbaceous

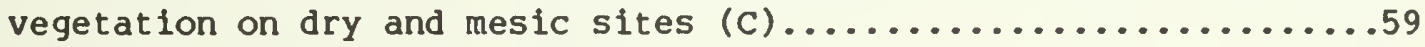

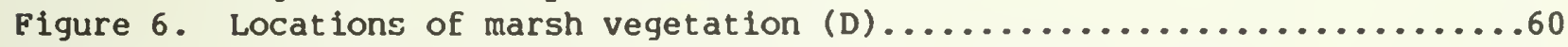

Figure 7. Distribution of Quercus muhlenbergi1 (Chestnut Oak)..........61

Figure 8. Distribution of Juncus secundus (One-side Rush) ............62

Figure 9. Distribution of Alisma gramineum (Grass-leaved Water-plantain) ...63 
Digitized by the Internet Archive in 2013

http://archive.org/details/descriptionanaly19857catl 


\section{RÉSUME}

Une étude floristique a été réalisée pour aider Parcs canada et d'autres organismes d'etat dans l'aménagement du marais de cataraqui, situé à la périphérie nord-est de Kingston, Ontario. L'information botanique a été recueillie en 13 excursions d'un jour chacune sur le terraín. On a récolté des plantes représentatives destinées à servir de matériel de recherche permanent. Les types de végétation observés à cet endroit comprennent six formes de boisés, deux de fourrés, au moins deux de milleux ouverts secs et huit de marais, plus trois catégories générales de végetation aquatique. Chaque type est décrit selon l'emplacement et la composition. Dans L'ensemble, les sites boisés plus secs sont à dominance de chêne rouge, alors que $1^{\prime}$ 'Erable à sucre l'emporte sur les pentes plus humides des affleurements calcaires. Le marais compte essentiellement trois espèces de Quenouilles (Typha), bien que dans certaines parties d'autres espèces vasculaires solent en dominance. La végétation aquatique, typique des eaux alcalines de la région, offre des espèces comme l'Élodée, la Vallisnérie, le Myriophylle en épi, le potamot pectiné et le Potamot crépu, la cornifle nageante, l'Hétéranthère et le Nénuphar blanc.

Le texte est accompagné d'une liste annotée des plantes vasculaires, indiquant le type, l'habitat, l'origine (indigène ou introduite) et précisant si on possède ou non une récolté ou une photographie des plantes répertoriées. La liste compte 472 espèces indigènes et 153 introduites, soit un total de 625 .

Bien qu le marais de Cataraqui contienne relativement peu d'espèces disjointes ou prés de la limite de leur aire normale de répartition, on y trouve des représentants de cinq groupes phytogéographiques intéressantes (méridional, occidental, appalachien, acidophile et calciphile). Le degré de diversité est extrêmement élevé à cause de la grande variété de substrats et d'expositions. Plus d'un tiers des plantes vasculaires trouvées dans la région centrale de Kingston (un territoire d'environ $1000 \mathrm{~km}^{2}$ ) $\mathrm{s}^{\text {'observent }}$ dans ce périmètre de moins de $10 \mathrm{~km}^{2}$. On trouve plus d'espèces aquatiques différentes dans le marais que dans la plupart des autres marais du réseau des Grands Lacs.

Le marais de cataraqui contient trois espèces vasculaires rares à l'échelle nationale, six rares et sept peu communes dans la province et 24 rares dans la région. Les espèces rares dans le pays et dans le province comprennent Jeffersonia diphylla, Juncus secundus, Quercus muhlenbergii, Carex artitecta, Crataegus brainerdil et Cinna arundinacea. Les espèces significatives sont largement dispersées dans le nord du territoire prospecté. Aucune communauté végétale ne présente d'importance particulière. Le marais et les habitats aquatiques offrent des potentialités très fortes comme aire de gagnage pour la sauvagine, du fait de la diversité, de L'abondance et de la disponibilité continue des plantes recherchées par les oiseaux aquatiques. 


\section{SUMMARY}

A botanical inventory was conducted to assist Parks Canada and other government agencies in the planning and management of Cataraqui Marsh on the northeast side of Kingston, Ontario. Information on the vegetation was gathered during 13 day-long field trips. Representative plants were collected to provide a permanent record and material for research. vegetation types present in the area include 6 types of woodland, 2 types of thickets, at least 2 types of dry open habitat, at least 8 categorles of marsh vegetation and 3 general categories of aquatic vegetation. Each type is described with regard to location and composition. In general, the drier woodlands are dominated by Red Oak while Sugar Maple is dominant on the moister slopes of limestone outcrops. The marsh is comprised mainly of three species of Cattails, but parts of it are dominated by other species of vascular plants. The aquatic vegetation is of a type characteristic of alkaline nutrient-rich water in the region and includes such species as waterweed, Tapegrass, European Water Milfoil, Sago Pondweed, Curly-leaved Pondweed, Coontail, Water Star Grass, and White Waterlily.

An annotated list of vascular plants found in the area is provided with notes on status and habitat, an indication of whether the plant is native or introduced, and whether or not there is a voucher specimen or photograph. This list includes 472 native and 153 introduced species; a total of 625 .

Although the Cataraqui Marsh area contains relatively few species that are disjunct or near their distributional limits, it does include representatives of 5 interesting phytogeographic patterns (southern, western, Appalachian, granite rock, and limestone rock). Diversity is unusually high due to the variety of substrates and exposures. Over $1 / 3$ of the vascular plants found in the central Kingston region (an area of approx. $1000 \mathrm{~km}{ }^{2}$ occur in this area of less than $10 \mathrm{~km}^{2}$. There are more different kinds of aquatic plants in the area than in most other marshes in the Great Lakes system.

The Cataraqui Marsh area contains 3 nationally rare, 6 provincially rare, 7 provincially uncommon and 24 locally rare vascular plants. The provincially and nationally rare species include Jeffersonia diphylla, Juncus secundus, Quercus muhlenbergil, Carex artitecta, Crataegus brainerdil and Cinna arundinacea. The significant species are widely dispersed in the northern portion of the area. No plant communities are considered significant in terms of species associations. The marsh and aquatic habitats have an unusually high potential as a waterfowl feeding area because of the diversity. abundance, and continuous availability of preferred waterfowl foodplants. 


\section{INTRODUCTION}

Cataraqui Marsh is situated on the northeast side of Kingston between $44^{\circ} 15^{\circ} 00^{\prime \prime}$ and $44^{\circ} 17^{\prime} 30^{\prime \prime} \mathrm{NL}$, and between $76^{\circ} 26^{\circ} 00^{\prime \prime}$ and $762^{\circ} 00^{\prime \prime}$ WL, in Frontenac County. It is part of the southern section of the Rideau Canal. Parks Canada, the ontario Ministry of Natural Resources, and the Cataraqui Region Conservation Authority all have some level of responsibility for the management of the area.

The Cataraqui Marsh has been identified as one of the most important wildife areas along the Rideau Canal system, (Lathem, 1976). Lists of vascular plants in various places in and around the marsh have been prepared by Beschel (1970), Garwood (see Lathem, 1977), Crowder (pers. comm., Fowler Herbarium, Queen's University), Hodges (1977) and Papilionis (1977). These lists have indicated high diversity and rare species but a detalled study of the vegetation of the marsh and its surroundings has never been conducted. Natural areas containing wetlands are assuming greater and greater significance, since wetland losses in southern ontario, and particularly along the Lake Ontario shore, have been substantial (Mccullough, 1981). The surviving wetlands contain a natural flora and fauna that has now been eliminated over extensive areas. Increasing numbers of migrating waterfowl and increasing recreational pressures, that were previously more widely dispersed, are now narrowly focussed on what is left. It is becoming ever more important to manage as effectively as possible those wetlands which can be protected. In order to improve their information base for planning and management, Parks Canada requested the help of the Biosystematics Research Institute of Agriculture Canada, in providing information on the occurrence of rare species and the types of vegetation present. Some of this information was presented in an unpublished report to Parks Canada (Catling, 1983), in a brief summary of botanical significance (Catling, 1985) and in a natural resource description with management considerations prepared by Blancher (1984). This publication represents a detailed presentation of the earlier work and includes the results of the 1984 field surveys as well as additional information provided by local naturalists.

Floristic information has application and interest beyond its direct use in planning and management. The Cataraqui Marsh area is one of the most floristically diverse sections of landscape traversed by highway 401 which crosses southern ontario from east to west, and many naturalists have speculated about its biological significance. Students of Queen's University and members of the Kingston Field Naturalists' club utilize the site for the study and enjoyment of plants and animals. Floristic information pertaining to this area is therefore of a more general interest as well.

Botanical inventories provide useful information on the composition of regional vegetation. Some inventories have furnished a basis for interesting comparisons. For example we know that the major aquatic weed in the navigation channel of the Cataraqui River has been in the Kingston region for less than 13 years since it was not recorded in a previous survey (Beschel et al.. 1970). Botanical inventories help to document the spread of introduced weeds as well as changes in the status of native species. The biologist is also provided with an indication of where certain plants may be found and studied.

Thus, this floristic study was undertaken with the hope that the results would satisfy the immediate needs, and also provide information that would be of long term use to naturalists and biologists. 
The study area is approximately $8 \mathrm{~km}^{2}$ in extent. It includes all of the open water and adjacent marshes and slopes of the lower Cataraqui River. At least $80 \%$ of the study area is marsh and aquatic habitat. Major features of the study area are illustrated in Figures 1 and 2.

The upper portion of the river (below Kingston Mills and above Highway 401) has a high granite ridge rising approximately $30 \mathrm{~m}$ above the river on either side. The well-drained substrates on these ridges have an acid reaction, in direct contrast to the substrates over much of the rest of the area which are alkaline.

Low escarpments of Black River limestone extend along either side of the lower marsh forming steep slopes to $25 \mathrm{~m}$ above the marsh. There are a few scarps to $5 \mathrm{~m}$ high, but most of the limestone is overlain by a stony calcareous glacial till. In lower areas this is mixed with clay giving rise to poorly drained alkaline soils (Lansdowne clay and Napanee clay) which are most prevalent at the north end (Gillespie, wicklund and Matthews, 1966). Where the parent material is coarser and well-drained, an acid surface reaction develops as on some of the higher islands and promontories.

A long history of European settlement has also had an influence on the vegetation of the area. Within a mile to the south is the site of Fort Frontenac, established in 1673. It is one of the earliest permanent establishments in eastern ontario. The more widespread settlement of Frontenac county began in 1783. The Rideau Canal was constructed following the war of 1812-14 to provide a military supply route. The long history of human pressure on the landscape has probably been most felt as the south end. clearing and farming have resulted in new habitats which are largely colonized by plants introduced from Europe.

Although there has been little detailed inventory work done in the Cataraqui area, it has not gone totally unnoticed. A resource management study for the area (Lathem, 1976) stresses biological values, makes recommendations regarding zoning changes and discusses existing and potential recreational uses. The area is not considered regionally significant from a biological viewpoint by the Ontario Ministry of Natural Resources (M.N.R., pers. comm.). It should be noted however, that the M.N.R. system of significant biological areas stresses the occurrence of significant species rather than concepts of diversity and wildife value which would rate unusually high for the Cataraqui Marsh area. The gorge at the north end of the area is considered to be a class 1 earth science feature by M.N.R. 


\section{METHODS}

During the summers of 1982, 1983 and 1984 a total of 13 day-long survey trips were made to the area (with 5 hours of field survey per trip). The surveys covered various times of the year from early spring to late fall so as to locate all species present in identifiable condition. The aquatic plant surveys were conducted in late summer and fall.

Dominant vegetation cover in various sections was recorded in a field notebook. In addition representative plants, collected as vouchers for the study, were deposited in the vascular plant herbarium of Agriculture Canada (DAO). Rare species were collected only in so far as was necessary to confirm and verify their identity. Photographs were taken to supplement the limited material of rare species collected.

These procedures enabled the preparation of an annotated checklist of vascular plants and a general description of vegetation. The results of the study were evaluated in terms of phytogeography, diversity, significant species, and significance to waterfowl and other wildlife, through reference to the literature. With regard to significant species, the central Kingston region (see Beschel et al.. 1970 p.V) was selected as the regional area. Taxa known from only one or two localities in this region (according to Beschel et al., 1970, and a 1983 survey of specimens in the Queens University herbarium) are considered to be locally rare. Provincial and National rarity is based on Argus and White (1977). "Provincially uncommon" is based on information gathered from herbarium collections (CAN, DAO, QK). 
RESULTS AND DISCUSSION

1. VEGETATION

A. Wooded Areas

A.1. Red Oak (Quercus borealis) dominated with some combination of Quercus alba, Quercus macrocarpa, Fraxinus americana, Prunus serotina, Pinus strobus and Populus spp.

\section{A.1.1. Red Oak on Bells Island}

The wooded areas on Bells Island are dominated by Red Oak with scattered Shagbark Hickory (Carya ovata) and Burr Oak (Quercus macrocarpa). In lower areas and along the shores are Black willow (Salix nigra) and White Ash (Fraxinus americana). An understory of shrubs and vines is well developed in some places, including Amelanchier sanguinea var. sanguinea, Prunus virginiana, Prunus interstitia, Rhamnus cathartica, viburnum lentago and Vitis riparia. Common herbs include Carex pensylvanica, Poa compressa, Fragaria virginiana, Luzula multiflora, Podophyllum peltatum, Thalictrum dioicum, viola septentrionalis, solidago funcea and waldsteinia fragarioides. In part of the woods that have been used as a picnic playground, excessive trampling has promoted such species as Poa pratensis, Poa annua, Poa compressa, Agrostis stolonifera, Taraxacum officinale and Festuca rubra.

\section{A.1.2 Red Oak on Granite Outcrops below Kingston Mills.}

The granite outcrops have a forest dominated by Red Oak with lesser amounts of White Ash (Fraxinus americana) and White Pine (Pinus strobus). In addition there are scattered white Oak (Quercus alba), Shagbark Hickory (Carya ovata), Black Cherry (Prunus serotina), Red Maple (Acer rubrum), Ironwood (Ostrya virginiana), Blue Beech (Carpinus caroliniana), Paper Birch (Betula papyrifera), Poplars (Populus spp.) and Red Cedar (Juniperus virginiana). In the lower areas and valleys of these outcrops, Sugar Maple (Acer saccharum), Basswood (Tilia americana) and Hemlock (Tsuga canadensis) are characteristic of valley bottoms and the steep NW-facing slope along the river below Kingston Mills is dominated by Eastern White Cedar (see A.4).

The east-facing and north-facing slopes have luxurient growths of Marginal Shield Fern (Dryopteris marginalis) and Rock Polypody (Polypodium virginianum), with Geranium robertianum, Solidago caesia, and Taxus canadensis.

The sites that are more exposed to the sun and consequently drier, are always dominated by Red Oak. This applies to the entire SE-facing outcrop forming the west shore of the upper Cataraqui River. The herb layer includes Agrostis perennans, Carex pensylvanica, Hystrix patula, Panicum xanthophysum, Prenanthes alba, Solidago caesia, Waldsteinia fragarioides, Aster macrophyllus and Veronica officinalis.

The tops and to a lesser extent the slopes of the granite outcrops are often only partially wooded with open shrubby clearings and exposed rock surfaces. Comon shrubs include Juniperus communis, Rubus flagellaris, Vaccinium angustifolium, Viburnum rafinesquianum, Rhus typhina, Diervilla lonicera, Cornus obliqua, Amelanchier arborea spp. arborea and Amelanchier alnifolia var. compacta. Varius grasses (Danthonia spicata, 
Poa compressa, Agrostis hyemalis, Deschampsia flexuosa, Panicum depauperatum var. involutum, Panicum implicatum and Panicum tuckermanil) dominate the open areas of shallow soil with Rumex acetosella, saxifraga virginiensis, Corydalis sempervirens, Solidago juncea, solidago hispida, selaginella rupestris, Aquilegla canadensis, Polygonum convolvulus, Fragaria virginiana, Commandra umbellata, and Woodsia 11 vensis also being important. Helianthus divaricatus, Trifolium aureum, Polygonum douglasii, Aralia hispida, Arctostaphylos uva-urs1, and Juncus secundus occur locally in open areas on the west ridge. At the southern end of the west ridge and in a few other places several introduced weedy species are common in the open dry clearings including Agropyron repens, Ambrosia artemisilfolia, Phleum pratense and Hypericum perforatum.

\section{A.1.3. North Woods \& North West Woods}

This woodland is dominated by Red Oak, White Oak (Quercus alba) and White Ash (Fraxinus americana) with an understory of Carpinus caroliniana, Cornus obliqua, Prunus virginiana, Rubus odoratus, Viburnum lentago and Viburnum rafinesquianum. The section north of Hwy. 401 is more complex. White Oak is somewhat less important here and Black Cherry (Prunus serotina) is more important, with lesser amounts of Bitternut Hickory (Carya cordiformis) and Shagbark Hickory (Carya ovata), Paper Birch (Betula papyrifera), Large-tooth Aspen (Populus grandidentata), Trembling Aspen (Populus tremuloides) and Beech (Fagus grandifolla). Frequent herbs throughout the area include Trillium grandiflorum, Erythronium americanum, Waldsteinia fragarioides, Solidago flexicaulis, Uvularia sessilifolia, Carex pedunculata, Podophyllum peltatum and Thallctrum diolcum. The lower depressions have a few Red Maples (Acer rubrum) and Silver Maples (Acer saccharinum) and Winterberry shrubs (Ilex verticillata). Impatiens biflora and Polygonum punctatum are prevalent in these lower depressions.

A.1.4. Red Oak dominated section of west limestone outcrop.

A limited section of the outcrop is Oak-dominated with Sugar Maple dominating the slopes on either side (A.2.2.). Burr Oak (Quercus macrocarpa) and Ironwood (Ostrya virginiana) are also important with lesser amounts of Chestnut Oak (Quercus muhlenbergi1), White Oak (Quercus alba) and Red Elm (Ulmus rubra). The understory includes Diervilla lonicera, Prunus virginiana, Poa compressa, Viburnum rafinesquianum, Carex pensylvanica, Solidago juncea, Helianthus divaricatus, Solidago flexicaulis, and Thalictrum diolcum.

A.1.5. Islands in the marsh and tips of promontories (see Fig. 3).

The forests are dominated by Red Oak with Burr Oak (Quercus macrocarpa) and White Oak (Quercus alba). The characteristic shrubs in the understory are Cornus obliqua, Cornus racemosa, Viburnum rafinesquianum and Viburnum lentago. Other shrubs such as Vaccinium angustifolium, Rhamnus catharticus, Lonicera dioica, sambucus canadensis, Sambucus pubens and Ceanothus americanus are present on some islands and promontories. 
The herb layer is well developed and includes Agrostis hyemal1s, Agropyron repens, Poa compressa, Poa pratensis, Festuca rubra, Danthonta splcata, Carex umbellata, Moehringla lateriflora, Waldstelnia fragarioldes, Malanthemum canadense var. Interius, Hypericum punctatum, scophularia lanceolata, Anemone quinquefolia, Solldago juncea and Solidago nemoralis.

Some parts of islands and promontories are so low as to have only calamagrostis canadensis. Island no. 2 has the only shrubs of Ceanothus americanus found in the area, and the most extensive stand of Carex foenea. The herbaceous flora of island no. 16 is particulary diverse, with Deschampsia flexuosa, Sisyrinchium montanum, Trifollum aureum, Carex artitecta, Luzula multiflora, Panicum linearifolium var. Ilnearifollum and Trisetum triflorum ssp. molle in addition to many of the characteristic species listed above.

\section{A.2. Sugar Maple (Acer saccharum) woodlands.}

\section{A.2.1. The East Limestone outcrop}

Much of the eastern limestone slope has been extensively cut. In many places the woodland is comprised of older essentially open-grown trees with horizontally spreading lower branches accompanied by a relatively dense growth of younger trees and saplings. In the northern section, the woodland is in a more natural state. The most frequent trees include sugar Maple (Acer saccharum), Red Oak (Quercus rubra). Shagbark Hickory (Carya ovata), White Ash (Fraxinus americana), American Elm (Ulmus americana) and Basswood (T1lia americana). White Pine (P1nus strobus), White Oak (Quercus alba), Yellow Birch (Betula lutea), Blue Beech (Carplnus caroliniana) and Ironwood (Ostrya virginiana) are also present with some Black Willow (Sallx nigra) along the marsh edges. The sporadic shrub layer is composed of Rhamnus cathartica, sambucus pubens, Cornus alternifolla, staphylea trifoliata, Ribes americanum, and Cornus stolonifera. In some more open areas, Vitis riparla, Solanum dulcamara and Rubus strigosus are common. Characteristic herbs on middle and lower slopes include Actaea rubra, Arlsaema triphyllum, Asarum canadense, Alliaria petiolata, Caulophyllum thallctroldes, Claytonia caroliniana, Circaea quadrisulcata, Erythronium americanum, Lapsana communis, Ranunculus abortivus, Trillium erectum, and carex cephalophora. The upper slopes have a sparse herb layer but Sugar Maple seedlings and Podophyllum peltatum are locally common.

A rocky talus area near the Fingers has Acer splcatum, Impatiens pallida, Cystopteris bulbifera, Dryopteris marginal1s, Dryopteris goldiana and Gerantum robertianum.

\section{A.2.2. West limestone outcrop.}

The west limestone outcrop is similar to the east limestone outcrop, but is somewhat drier and a part of it is dominated by oak (A.1.4). To the north and south of the oak area, the woodland is dominated by Sugar Maple, Red Oak (Quercus borealis). White Ash (Fraxinus americana) and Basswood ( $T 111$ a americana) with Black Cherry (Prunus serotina) becoming more important at the south end where the forest has been severely cut. Shagbark Hickory (Carya ovata), Red Elm (Ulmus rubra), Ironwood (Ostrya virginiana) and Beech (Fagus grandifolla) are also present. Since the slope is relatively 
dry and steep, the ground cover is sparse. Characteristic species include Asarum canadense, Solldago flexicaulis and Thalictrum dlolcum with lesser amounts of Geranium maculatum, Gerantum robertianum, Ranunculus abortivus and Trillium grandiflorum. Where the slope is more open, Diervilla lonicera, Viburnum rafinesquianum, Prunus virginiana, Cornus racemosa, Poa compressa, Carex pensylvanica and Helianthus divaricatus are prominent.

\section{A.3. Eastern Hemlock (Tsuga canadens1s), White Pine (Pinus strobus).}

The open Red Oak vegetation types characteristic of the islands and tips of promontories grades into this conifer dominated woodland at the base of promontories (The Fingers). There are numerous weak springs in this area, or at least surfacing of ground water, at the base of Hemlock-dominated slopes with little herbaceous ground cover. Herbs include Malanthemum canadense, solldago caesla, Carex pedunculata and Poa compressa. At bases of slopes in wet seepy areas, Impatiens biflora, Onoclea sensibilis, Carex retrorsa and Glycerla spp. are prevalent.

A.4. White Cedar (Thuja occidental1s) slope

Along the east granite outcrop beside the river, the steep Nw-facing granite slopes are covered with white cedar and extensive growth of ferns (Dryopteris marginalis, Polypodium virginianum). This is a very narrow zone within A.1.2.

\section{A.5. Disturbed second growth woods}

These areas are identified on the basis of a substantial component of introduced trees and shrubs. The slope south of Barkers Point provides a good example. The abundance of Manitoba Maple (Acer negundo) near the quarry represents a similar situation in an earlier stage of development. South of Barkers Point there are extensive thickets of escaped Lilac (syringa vulgaris) along with Rhamnus catharticus, Ribes sativum, Acer negundo and Lonicera tatarica and old apple trees (Pyrus malus). Native trees and shrubs are also present including shagbark Hickory (Carya ovata), Sugar Maple (Acer saccharum) Black Cherry (Prunus serotina), Choke Cherry (Prunus virginiana), Wild Raspberry (Rubus strigosus), Blackberry (Rubus allegheniensis), and staghorn sumac (Rhus typhina). Herbaceous species include Solidago canadensis, Fragarla virginiana, Geum canadense, Ranunculus acris, Alliaria petiolata, Hesperis matronalis, Campanula rapunculoides, Prunella vulgaris and Arctium minus. Various cultivated plants persisting or spreading around old foundations suggest earlier habitation. The persisting or spreading cultivated species include Ribes sativum, Convallaria majalis, Ornithogallum umbellatum, Crocus sativus, Malus sylvestris, Ligustrum vulgare and Valeriana officinalis. The reports of Trillium viride and Mertensia virginica both found in the point area by A.E. Garwood (Lathem, 1976) were probably also persisting from cultivation. 


\section{A.6. Pine Plantation}

This area has a dense stand of planted scots Pine (Pinus sylvestris) and Norway Spruce (Plcea ables). There is no substantial shrub or herb layer.

\section{B. Thickets}

\section{Bl. Speckled Alder (Alnus rugosa)}

In addition to speckled Alder, Winterberry (Ilex verticillata) and Chokeberry (Aronia prunifolia) may be present. Characteristic herbs in more open portions of the thickets include onoclea sensibilis, Glyceria spp., Thelypteris palustris, Alisma plantago-aquatica, Leersia oryzoides, Muhlenbergia mexicana, Carex comosa, Carex tenera, Eleocharis elliptica, Calla palustris, Solanum dulcamara, Polygonum spp., Caltha palustris, Nasturtium officinale, Veronica anagallis-aquatica, Lythrum salicaria, and Clcuta bulbifera. Thelypteris palustris, Bidens cernua, Biden frondosa and Sagittarla cuneata are abundant on the muddy flats in late summer. The alder thickets occur around springs at the edge of the marsh. Alder thickets in a boggy pocket near the Fingers had sphagnum hummocks with Osmunda cinnamomea, Osmunda regalis and Carex leptalea. palustris, Bidens cernua, Bidens frondosa and saggittaria cuneata are abundant on the muddy flats.

\section{B.2. Hawthorn (Crataegus spp.)}

The dominants are various species of Hawthorns (Crataegus macrantha, $C$. chrysocarpa, C. punctata, and C. submolits) occasionally with other shrubs (Cornus racemosa, Zanthoxylum americanum, viburnum lentago, and Cornus obliqua). Ground cover beneath the shrub cover is limited by both shade and rate of colonization of shade tolerant species. Common herbs beneath and around the shrubs include Poa compressa, Fragaria virginiana, Prunella vulgaris, Ranunculus acris, Poa pratensis, Agrostis stolonifera, Festuca rubra, Geum canadense, Solidago canadense and Agrimonia gryposepala.

C. Open Herbaceous vegetation on dry and mesic sites

\section{C.1. Pasture and Meadow}

These areas are dominated by grasses including Poa pratensis, Poa compressa, Agropyron repens, Agrostis stolonifera, Dactylis glomerata, Phleum pratense and Festuca rubra. Other characteristic species include Medicago lupulina, Trifolium repens, Trifollum pratense, Daucus carota, Plantago lanceolata and Prunella vulgaris.

The pasture land north of Barkers Point (C.1.3) has large open-grown trees of Shagbark Hickory (Carya ovata), Black Maple (Acer nigrum), American Elms (Ulmus americana), White Oak (Quercus alba) and Burr Oak (Quercus macrocarpa). Common shrubs include Rosa multiflora, Berberis vulgaris and Juniperus communis. An introduced sedge, Carex spicata, is particularly comon in this pasture area. 
The pasture area at the north end (C.1.4) has developing Hawthorn thickets (B.2.) and scattered wet hollows with sedges, rushes, and spikerushes (Carex spp., Juncus spp., Eleocharis spp.).

\section{c.2. Open disturbed ground}

These habitats occur in situations where the native vegetation has been destroyed, severely altered, or where new habitat for colonization has been created (e..g. around buildings, along roadways and railways, industrial sites, fill, dredge spoil, etc.). In some of these situations the disturbance (trampling, cutting, use of herbicides, etc.) is continuous. Two extensive disturbed areas occur in the study area, and many plants characteristic of these areas were not encountered elsewhere.

In the railway gravel Diplotaxis tenuifolia, salsola kali var. tenuifolia, Corydalis aurea, Setaria viridis and Equisetum arvense are frequent. On the railway banks a variety of plants occur including Agropyron repens, Bromus spp., Rubus strigosus, Rhus radicans var. rydbergi1, Arctium minus, Sanguinaria canadensis, Lithospermum officinale, Fragaria virginiana, Celastrus scandens, Oenothera biennis, Saponaria officinalis, Dactylis glomerata, Lolium perenne and Asclepias syriaca.

The gravelly open limestone around and below the quarry has the following species: Phleum pratense, Poa compressa, Agrostis stolonifera, Agropyron repens, Solidago nemoralis, Chrysanthemum leucanthemum, Melilotus alba, Echium vulgare, Clchorium intybus, Solidago juncea, Arctium minus, Cirsium vulgare, Centaurea spp., Solidago canadensis, Daucus carota, Trifolium spp.. Lotus corniculatus, and Ambrosia artimesiffolia. Frequent woody species here include Acer negundo, Rhus typhina, and Rubus strigosus.

\section{c.3. Open granite bald}

The characteristic vegetation of such sites is treated as clearings in Oak woodland and is described under A.I.I.

\section{Marsh Vegetation}

The marsh vegetation is complex. It is certainly not a monospecific stand of cattails (see under "Diversity"), but the relative areas of different kinds of marsh vegetation are difficult to assess and the recognizable types of vegetation themselves intergrade making the limits somewhat arbitrary. Aerial photographs show vegetation patterns but these do not always correspond to major vegetation types. This impression of complexity and variability in the Cattail Marsh, based on aerial photography, is confirmed upon exploring it. Possibly as much as $30 \%$ of the marsh area is sedge and graminoid marsh with the remainder being some type of Cattail Marsh.

A variable zonation of marsh vegetation is apparent in transects from the edge toward the river. Bluejoint, Reed Canary Grass-Sedge meadows (D.l.1., D.1.2.) occur on the higher edges and on high places within the marsh. The Spike Rush marsh (D.1.3.) occurs in periodically deeply flooded depressions within this zone. Wide-leaved Cattail ( $T$. latifolia) occurs in deeper and wetter portions of the marsh whereas the interior and drier portions have narrow-leaved cattail ( $T$. angustifolia). The border of the marsh adjacent to the channels and river have hybrid cattail ( $T$. X glauca). Within the 
Cattail marsh are floating sedge mats (D.1.5.) and stands of Glant Reed (D.1.6.). The deep sedge marsh (D.1.4.) vegetation occurs along shores and edges of cattail marsh.

D.1. Sedge and graminoid marsh

D.1.1. and 2. Blue joint (Calamagrostis canadensis) and sedges (Carex spp.)

This type of vegetation is characteristic of the higher edges of cattail marshes (D.2.). Bluejoint varles from almost total dominance (D.1.1.), to low importance with the sedges being dominant (D.1.2.). The dominant sedges include carex stricta, Carex aquatilis and Carex lacustris. Where the sedges are dominant the plant community is more diverse. Other important species include carex lanuginosa, Carex atherodes, Thelypteris palustris, Potentilla palustris, Campanula aparinoides, Eupatorium perfollatum, Bupatorium maculatum, Lathyrus palustris, Teucrium canadense, Convolvulus sepium, scutellaria galericulata, Asclepias incarnata, Mentha arvensis, solidago graminifolia, Phalaris arundinacea, stachys tenuifolla and Verbena hastata.

\section{D.1.3. Spike Rush (Eleocharis smalli1) Marsh.}

These areas are dominated by Eleocharis smalli1 with Carex aquatilis, scirpus cyperinus, Calamagrostis canadensis, Sparganium eurycarpum and Carex crinita.

\section{D.1.4. Deep Sedge Marsh}

In some places along the shore, there are rich stands of emergent vegetation including Scirpus fluviatilis, Eleocharis smalli1, Butomus umbellatus, Scirpus validus, Sparganium eucycarpum, Phalaris arundinacea, Typha latifolia, Typha X glauca, Hydrocharis morsus-ranae, Sagittarla latifolia and submersed Lemna trisulca.

\section{D.1.5 Floating Sedge Mat}

Floating mats of various size are scattered throughout the cattail marsh. The most important species on many of these floating mats is Carex lasiocarpa. Other important species are Carex lacustris, Carex prairea or diandra, Typha latifolia, Calamagrostis canadensis, Acorus calamus, and Potentilla palustris.

\section{D.2. Cattail (Typha) Marsh}

The species that occur with $T$. X glauca, in the northwest corner of the marsh and along the edges of the channels are Phalaris arundinacea, Bldens cernua, Bidens frondosa, Cicuta bulbifera, Veronica anagallis-aquatica, Lythrum salicaria, Lemna spp. and Wollfia spp. With $T$. angustifolia in the central portions of the marsh are Naumbergia 
thyrsiflora, Potentilla palustris and Potamogeton gramineus. The wide-leaved cattail, ( $T$. latifolia) occurs with many marsh species including sium suave, Lythrum salicaria, Lycopus spp., Galium spp., and Impatiens biflora, and often with the other cattails.

\section{E. Aquatic Vegetation}

Along the main channel of the Cataraqui River there is considerable water movement due to both periodic high water and the Rideau canal boat traffic. The narrower section (above the highway 401 bridge) has the most rapid current. Characteristic aquatics in this section include Myriophyllum spicatum, Vallisneria americana, Najas flexilis, Potamogeton nodosus and in water over $1 \mathrm{~m}$ deep, Najas guadalupensis. The lower section of the main channel (below the highway 401 bridge) is dominated by Vallisneria americana with some Potamogeton crispus and Potamogeton pectinatus and lesser amounts of $P$. richardsonil and Myriophyllum spicatum.

The water of the main channel is frequently cloudy either due to disturbance of the substrate or to algal blooms originating in Colonel By lake and other lakes in Rideau system upstream. The cloudiness in the main channel is in sharp contrast to clear water in the two streams in the marsh entering the main channel from the west. Undoubtedly there are differences in water chemistry and substrate that are associated with the differences in clarity, and it is not surprising that there are differences in the vegetation. The marsh channels are without Vallisneria americana and Myriophyllum spicatum but instead have dense growth of Najas flexilis, Heteranthera dubia, Ceratophyllum demersum, utricularia vulgaris and Nymphaea tuberosa. Potamogeton pectinatus, Potamogeton crispus, Elodea canadensis, Nuphar variegatum and Myrlophylium exalbsecens are also quite common. Both of the marsh channels have large stands of wild Rice zizania palustris var. palustris.

Several specles were found only along the borders of the main channel water and the marsh channel water. Included in this category are Bidens becki1, Potamogeton natans, and Potamogeton epihydrus var. ramosus.

The large section of open water north of Bells Island on either side of the main channel is dominated by Elodea canadensis, Potamogeton crispus, Ceratophyllum demersum and Heteranthera dubia. Potamogeton crispus and Myriophylium spicatum dominate much of the area early in the season, but they begin to die back in mid-June. By late summer, the other species appear to be the most important. Vallisneria americana, Nymphaea tuberosa, Lemna trisulca and Myriophyllum spicatum are locally important. 


\section{ANNOTATED LIST OF VASCULAR PLANTS OF THE CATARAQUI MARSH STUDY AREA}

In the following list, species are organized in the usual phytogenetic sequence of families following Gleason and Cronquist (1963), but within the families, the genera and within them, the species, are arranged alphabetically. An indication of status is given by "rare" (1-2 stations). "occasional" (3-6 stations), and "common" (over 6 stations) where stations are defined as locations of occurrence more than $100 \mathrm{~m}$ apart. In addition, the general habitat and location in the study area is provided. Introduced (i.e. non-native) species are indicated with "I" before the name. Species for which collections were made (totalling 295 species and 352 collections) are indicated with an asterisk(*).

\section{LYCOPODIACEAE}

Lycopodium digitatum A.Braun (L. complanatum var. flabelliforme)

Rare, west granite outcrop.

Lycopodium lucidulum Michx.

Rare, east granite outcrop.

Lycopodium dendroideum Michx. (L. obscurum)

Rare, west granite outcrop.

\section{SELAGINELLACEAE}

* Selaginella rupestris (L.) Spreng.

Rare, open granite outcrop on west side of upper Cataraqui River.

\section{EQUISETACEAE}

Equisetum arvense L.

Common, disturbed open ground

Equisetum hyemale L.

Rare, along the railway.

* Equisetum palustre L.

Occasional, along the east shore

Equisetum varlegatum Schleich.

Rare, wet meadow below the quarry.

\section{OPHIOGLOSSACEAE}

Botrychium matricariaefolium A.Br.

Rare, deciduous woods on east side.

Botrychium virginianum (L.) Sw.

Rare, deciduous wood at north end.

\section{OSMUNDACEAE}

Osmunda cinnamomea L.

Rare, boggy lowland near the Fingers.

Osmunda claytoniana L.

Rare, wooded edge of lowland near the Fingers.

Osmunda regalls L. var. spectabilis (willd.) Gray

Rare, boggy lowland near the Fingers.

\section{ASP IDIACEAE}

Adiantum pedatum L.

Rare, deciduous woods on east side.

* Athrium felix-femina (L.) Roth

Common, woodlands throughout. 
* Athyrium thelypteroides (Michx.) Desv.

Rare, base of wooded limestone talus near the Fingers.

Cystopteris bulbifera (L.) Bernh.

Rare, wooded limestone talus near the Fingers.

Cystopteris fragilis (L.) Bernh.

Common, moist places on rocky outcrops.

Dryopteris carthusiana (Vill.) H.P. Fuchs (D. spinulosa)

Rare, rocky woods near the Fingers.

Dryopteris cristata (L.) Gray

Rare, swampy woods near the Fingers and moist rocky faces on west

granite outcrop.

* Dryopteris goldiana (Hook.) Gray

Rare, rocky wooded limestone talus on east side.

Dryopteris intermedia Muhl.

Rare, rocky woods near the Fingers.

* Dryopteris marginalis (L.) Gray

Common, rocky woods.

* Dryopteris $x$ triploidea Wherry

Rare, north-facing slope at north end of east granite outcrop.

Gynocarpium dryopteris (L.) Newn.

Rare, woods at north end.

Matteuccia struthiopteris (L.) Todaro

Rare, moist seepy areas along slope on east side.

onoclea sensiblis L.

Common, marsh and wet woods.

* Polypodium virginianum L.

Common, granite rock outcrops at north end.

polystichum acrostichoides (Michx.) Schott.

Occasional, deciduous woods.

Pteridium aquilinum (L.) Kuhn

Occasional, dry semi-wooded slopes and islands in the marsh.

* Thelypterls palustris schott.

Common, open marsh and swampy woods.

* Woodsia ilvensis (L.) R.Br.

Common, granite outcrops at north end.

\section{TAXACEAE}

* Taxus canadensis Marsh.

Common, wooded granite outcrops at north end.

\section{PINACEAE}

Ables balsamea (L.) Mill.

Rare, low place on east granite outcrop.

Larix laricina (Du Roi) K. Koch.

Rare, boggy lowland near the Fingers.

Plcea glauca (Moench) Voss

Rare, granite outcrop at north end.

Pinus resinosa Ait.

Rare, granite outcrop at north end.

Pinus strobus L.

Common, mostly on the east side.

I Pinus sylvestris L.

Rare, south side of pasture at north end.

Tsuga canadensis (L.) Carr.

Common, mostly on the granite outcrops at the north end. 


\section{CUPRESSACEAE}

* Juniperus communis L.

Occasional, especially on granite outcrops at north end.

Juniperus virginiana L.

Occasional, outcrops, fields and islands in the marsh.

\section{TYPHACEAE}

* Typha angustifolia L.

Common, central portions of main marsh and marsh edges.

* Typha $x$ glauca Godr.

Common, edges of channels and river and north west corner of main marsh.

* Typha latifolia L.

common, central portions of the main marsh and marsh edges.

\section{SPARGANIACEAE}

Sparganium chlorocarpum Rydb.

Rare, edge of main channel above hwy. 401.

* Sparganium eurycarpum Engelm.

occasional, edges of main river channel.

\section{NAJADACEAE}

* Najas flexilis (willd.) Rostk.

Common throughout in water to $2 \mathrm{~m}$ deep.

* Najas guadalupensis (spreng.) Magnus

Common, especially in upper portions of Cataraqui River.

Zannichellia palustris L.

Rare, washed ashore at Bells island.

Potamogeton amplifolius Tuckerm.

Occasional, in water to $2 \mathrm{~m}$ deep, south bay north of Bells Island.

*I Potamogeton cripus L.

Common in lower end of cataraqui River.

* Potamogeton epthydrus Raf. var. ramosus (Peck) House

Occasional, in the upper fast portion of the Cataraqui River and edge of lower marsh.

* Potamogeton filiformis Pers. var. alpinus (Blytt) Aschers \& Graebner

Rare, only in channel or east side of upper marsh.

* Potamogeton gramineus L.

Occasional, in shallow water in main Cattail marsh.

* Potamogeton natans L.

occasional, protected bays in main marsh.

* Potamogeton nodosus Poir.

Rare, only in the upper fast portion of the Cataraqui River.

* Potamogeton pectinatus L.

common, in water to $2 \mathrm{~m}$ deep.

* Potamogeton perfoliatus L.

Occasional, east wide of marsh \& near Bells Island.

* Potamogeton pusillus L. var. pusillus

Common, especially in marsh channels.

* Potamogeton pusillus L. var. tenuissimus Mert. \& Koch. comon, mostly in the main marsh area.

* Potamogeton Iichardsoni1 (Benn.)Rydb.

Common, in water to $2 \mathrm{~m}$ deep.

* Potamogeton zosteriformis Fern.

Occasional, around the main marsh and in the marsh channels. 


\section{ALISMATACEAE}

* Alisma gramineum Lej.

Rare, limestone pavements along lower east shore in water to $1 / 2 \mathrm{~m} \mathrm{deep}$.

* Allsma plantago-aquatica L. (sensu lato)

Common, in water and wet open places.

* Sagittarla cuneata Sheldon

occasional, on mud flats around marsh and in isolated pools near the fingers.

Sagittaria latifolia willd.

Common, cattail marsh.

* Sagittarla rigida Pursh.

occasional, outer edges of cattail marsh.

\section{BUTOMACEAE}

*I Butomus umbellatus L.

Common, edges of marsh \& shorelines in water to $1 / 2 \mathrm{~m}$ deep.

\section{HYDROCHARITACEAE}

Elodea canadensis Michx.

Common, in water to $2 \mathrm{~m}$ deep.

* Vallisneria americana Michx.

Common, boat cannel and lower portion of river.

*I Hydrocharis morsus-ranae L.

Common, edge of main marsh and east shore

\section{POACEAE}

I Agropyron repens (L.) Beauv.

Common, open meadows, pastures \& disturbed areas

* Agrostis hyemalis (Walt.) BSP.

Occasional, granite outcrops and islands in the marsh.

* Agrostis perennans (Walt.) Tuckerm.

Rare, semi-open areas on west granite outcrop.

I Agrostis stolonifera L.

Common, open meadows, pastures, wet meadows.

Agrostis gigantea Roth.

Common, wet meadows.

* Alopecurus aequalis sobol.

Occasional, edges of islands on the east side of the river and elsewhere in the marsh.

I Alopecurus pratensis L.

Rare, moist ditch near Hwy. 401.

I Avena sativa L.

Rare, along the railway tracks.

Brachyelytrum erectum (Schreb.) Beauv.

Rare, granite outcrop in woods.

Bromus ciliatus L.

Common, meadows.

I Bromus inermis Leyss.

Common, meadows.

I Bromus tectorum L.

Rare, along the rallway and bank near the quarry.

* Calamagrostis canadensis (Michx.) Beauv.

Common, wet meadows and marsh.

Cinna arundinacea L.

Rare, moist woods near the Fingers. 
Cinna latifolia (Trev.) Griseb.

Occasional, moist woods.

I Dactylis glomerata L.

Common, open ground.

* Danthonia spicata (L.) Beauv.

Common, granite outcrops and islands in the marsh.

* Deschampsia flexuosa (L.) Trin.

Rare, open areas on granite outcrop.

I Digitaria ischaemum (Schreb.) Muhl.

Rare, disturbed open ground

I Digitaria sanguinalis (L.) Scop.

Rare, disturbed open ground.

I Echinochloa crusgalli (L.) Beauv.

Rare, disturbed open ground.

Echinochloa wiegandil (Fassett) McNelll \& Dore

Rare, edge of the main marsh at the NW corner.

* Echinochloa microstachya (wieg.) Rydb.

Rare, disturbed open ground near quarry.

* Elymus canadensis L.

Rare, Bells Island and railway track.

Elymus virginicus L.

Common, shorelines and woodland edges.

Eragrostis pectinacea (Michx.) Nees

Rare, picnic area Bells Island.

I Eragrostis poaeoldes Beauv.

Rare, shore west of Bells Island.

I Festuca arundinacea Schreber

Rare, meadow near Hwy. 401 on east side.

* Festuca rubra L.

Common, especially on marsh islands and the Fingers.

* Glyceria canadensis (Michx.) Trin.

Occasional, marsh edge.

* Glyceria grandis S. Wats.

Common, marsh edges and shores.

* I Glyceria maxima (Hartm.) Holmb.

Common, marsh edges and shores in water to $0.5 \mathrm{~m}$ deep.

* Glyceria striata (Lam.) Hitchc.

Occasional, moist shaded areas at edge of marsh

* Hierochloe odorata (L.) Beauv.

Rare, railway tracks on west side.

I Hordeum jubatum L.

Occasional, disturbed ground.

* Hystrix patula Moench.

Common, wooded areas especially on east side.

Leersia oryzoldes (L.) Sw.

occasional, wet meadows.

Leersia virginica Willd.

Rare, depressions in deciduous woods on east side.

I Lolium multiflorum Lam.

Rare, distrubed ground on east side near quarry.

I Lollum perenne L.

Rare, railway tracks.

Milium effusum L.

Rare, woods on east side near quarry. 
Muhlenbergia mexicana (L.) Trin.

Common, distrubed wooded areas.

oryzopsis asperifolla Michx.

Rare, dry oak woods on granite at north end.

* Panicum capillare L.

Occasional, dry open ground, west granite ridge.

* Panicum depauperatum Muhl. var. involutum (Torrey) A. Wood

Rare, dry woods on west limestone outcrop.

* Panicum implicatum Scribner ( $P$ lanuginosum var. Implicatum)

occastonal, open gravelly areas.

* Panicum lanuginosum Elliot var. fasciculatum (Torrey) Fern.

Rare, granite ridge top on west side of the river.

Panicum Ilnearifollum Scribner

Occasional, dry granite ridge, islands and promontories in the marsh.

Panicum tuckermanil Fern.

Rare, open areas on west granite outcrop.

Panicum xanthophysum A. Gray

Rare, in dry oak-pine woods on west granite ridge.

* Phalaris arundinacea L.

Common, marsh and wet meadow.

I Phleum pratense

Common, meadows and open ground.

Phragmites australls (Cav.) Steudel ( $P$. communts)

occasional, main marsh and east side.

* I Poa annua L.

Occasional, disturbed ground, Bells Island.

I Poa compressa L.

Common, dry rock outcrops and pastures.

* Poa palustris L. Common, wet meadows.

* Poa pratensis L.

Common, open meadows and open woods!

I Puccinellia distans (L.) Parl.

Rare, disturbed open ground below quarry.

Schlzachne purpurascens (Torr.) Swallen

Rare, dry granite ridge south of locks.

I Setarla glauca (L.) Beauv.

Rare, rallway tracks.

I Setaria viridis (L.) Beauv.

Common, open ground.

Sphenopholis intermedia (Rydb.) Rydb.

Occasional, wet meadows.

sporobolus neglectus Nash

Rare, open dry portion of meadow west of Bells Island

sporobolus vaginiflorus (Torr.) wood

Rare, open dry portion of meadow west of Bells Island.

Torreyochloa pallida (Torrey) Church var. fernaldil (A.S. Hitchc.)

Dore ex

Koyama \& Kawano

Rare, molst swampy woods near the Fingers.

* Trisetum triflorum (Blgel.) A.\& D. Love ssp. molle (Hultén) A.\& D. Love Occastonal, on the marsh 1slands.

* Zizania palustris L. var. palustris ( 2 . angustifolia)

Occasional, in the marsh channels. 


\section{CYPERACEAE}

* Carex amphibola Steudel var. turgida Fern.

Rare, disturbed woods south of Barkers Point.

* Carex aquatilis Wahl.

Common, marsh and wet meadows.

Carex arctata Boott

Occasional, deciduous woods.

* Carex artitecta Mack. (c. nigromarginata var. muhlenbergi1)

Rare, dry open locations on marsh islands and promontories.

* Carex atherodes Spreng.

Occasional, marsh and wet meadows.

* Carex bebbi1 olney

Damp area on west granite ridge, status uncertain.

* Carex blanda Dewey

Occasional, east limestone outcrop.

Carex brevior (Dewey) Mack.

Wet meadow north of the Fingers. Status in the study area uncertain.

* Carex cephalophora willd.

Occasional, deciduous woods over limestone.

* Carex communis Bailey

Occasional, wooded areas

* Carex comosa Boott

Common, marsh.

carex crinita Lam.

Common, marsh and marsh edges.

* Carex cumulata (Bailey) Mack.

Occasional, west granite outcrop.

Carex deweyana Schw.

Rare, woods on east side.

* Carex diandra Schrank

Floating mats and edges of the main marsh at the south end, status uncertain.

Carex eburnea Boott

Rare, open slope near the Fingers.

* Carex foenea willd. (c. siccata).

Rare, islands in the marsh west of the river.

Carex gracillima Schw.

Rare, deciduous woods.

* Carex granularis Willd.

Common, open and often distrubed areas.

Carex hystricina Muhl.

Occasional, wet meadows.

* Carex lacustris Ehrh.

Common, marsh edges.

* Carex lanuginosa Michx.

occasional, marsh edges.

* Carex lastocarpa Ehrh.

Common, floating mats in the marshes.

Carex laxiflora Lam.

Occasional, deciduous woodlands.

* Carex Leptonervia Fern.

Occasional, woods on east side.

* Carex leptalea Wahl.

Rare, boggy depression near the Fingers. 
*I Carex pallescens L.

Rare, low meadow near Barkers Point.

Carex pedunculata Muhl.

Common, wooded areas

* Carex pensylvantca Lam.

Common, dry wooded areas, crests of outcrops.

Carex plantaginea Lam.

Rare, deciduous woods on east side.

* Carex pralrea Dewey

wet meadows North of the Fingers, status in the area uncertain.

* Carex pseudo-cyperus L.

Common, marsh.

* Carex radiata (wahl.) Small (c. rosea of recent authors).

Occasional, wooded areas.

* Carex retrorsa Schw.

Occasional, edges of marsh.

Carex rosea schkuhr (c. convoluta of recent authors).

Occasional, wooded areas.

* Carex rugosperma Mack.

Rare, open barren ground on top of west granite outcrop at north end.

* Carex sartwellil Dewey

Rare, near edges of main marsh at south end and along railway.

* Carex sparganioldes Willd.

Rare, island on east side of marsh south of Hwy. 401.

* I Carex spicata Huds.

Common, woods and pastures.

* Carex stipata willd.

Common, wet meadows.

* Carex stricta Lam.

Common, marsh \& wet meadow.

Carex tenera Dewey

Common, wet meadows and wet woods.

* Carex tribuloldes Wahl.

occasional, wet meadows.

Carex tuckermant1 Boott

Rare, swampy wood near the Fingers.

Carex umbellata schkuhr

occasional, dry granite ridge top and dry open areas on islands and promontories.

carex vesicaria L.

Occasional, wet meadow and marsh.

Carex viridula Michx.

Rare, wet meadow south of Hwy. 401 on east side of river.

Cyperus rivularis Kunth

Rare, only on a sandy beach on Bells Island.

* Cyperus strigosus L.

Rare, dredge spoll along the upper river.

Eleocharis actcularis (L.) R.\& S.

Common, main Typha marsh and along rocky shore of upper river where exposed in late summer and fall.

Eleocharis elliptica Kunth

Common, marsh and wet meadows.

Eleocharts erythropoda steud.

Common, marsh and wet meadow. 
* Eleocharis obtusa (willd.) Schult. (E. ovata)

occasional, muddy areas becoming dry in late summer and on dredge spoil.

* Eleocharls smallil Britton (E. palustris)

Common, marsh edges in water to $1 / 2 \mathrm{~m}$ deep.

Scirpus acutus Muhl.

Common, marsh and marsh edges in water to $1 / 2 \mathrm{~m}$ deep.

scirpus pungens vahl. ( $S$. americanus)

Common, drier portions of marsh and marsh edges.

Scirpus cyperinus (L.) Kunth

Rare, in a spikerush marsh with Buttonbush on north side of Hwy. 401

west of the river.

* Scirpus fluviatilis (Torr.) Gray

Common, marsh edges and shore in water to $1 / 2 \mathrm{~m}$ deep.

* Scirpus validus Vahl

Common, marsh and marsh edges in water to $1 / 2 \mathrm{~m}$ deep.

\section{ARACEAE}

* Acorus calamus L. sensu lato

Common, marsh and wet meadows.

* Arisaema triphyllum (L.) Schott

Common, deciduous woods.

* Calla palustris L.

Occasional. Typha marsh on floating mats and boggy depression near the Fingers.

\section{LEMNACEAE}

* Lemna minor L.

Common, floating in marsh channels, pools and sheltered bays.

* Lemna trisulca L.

Common, marsh and edge of river.

* Spirodela polyrhiza (L.) Schleiden

Common, marsh areas.

* Wolffia columbiana Karst.

Occasional, sheltered pools in marsh.

* Wolffia borealis (Engelm.) Landolt (W. punctata)

occasional, sheltered pools in marsh, very common in NW corner.

\section{PONTEDERIACEAE}

Pontederia cordata L.

Rare, edge of lower marsh on west side of Cataraqui River.

* Heteranthera (Zosterella) dubia (Jacq.) Small

Common, in water to $2 \mathrm{~m}$ deep.

\section{JUNCACEAE}

Juncus alpinoarticulatus Chaix. In villars (J.alpinus)

Rare, east shore north of Barkers Point.

Juncus dudleyi wieg.

Common, wet meadows, shores and disturbed open places.

Juncus effusus L.

occasional, wet meadows, pastures and shores.

* Juncus secundus Beauv.

Rare, open granite ridge-top on west side of the upper Cataraqui River.

* Juncus tenuis Willd.

Comon, pasture and disturbed open ground. 
* Juncus vaseyi Engelm.

Rare, open granite ridge top on west side of upper Cataraqui River. Luzula acuminata Raf.

Rare, dry open ground on granite ridge and islands in the marsh.

Luzula multiflora (Retz.) Lej. (L. campestris)

Occasional, dry open ground on granite ridge and islands in the marsh.

\section{LILIACEAE}

Allium canadense L.

Rare, base of west granite outcrop.

Allium tricoccum Ait.

Occasional, deciduous woods on east side.

Asparagus officinalis L.

Rare, along the railway.

Clintonia borealis (Alt.) Raf.

Rare, rocky woods on granite outcrop.

I Convallaria majalis L.

Rare, spreading from old home side south of Barkers Point.

* Erythronium americanum Ker.

Common, wooded areas throughout.

*I Hemerocallis flava L.

Occasional, south of Barkers Point and along the railway.

Malanthemum canadense Desf. var. Interlus Fern.

Common, dry crests of islands and promontories and granite outcrops.

*I Ornithogallum umbellatum L.

A few plants persisting south of Barkers Pt.

Polygonatum pubescens (willd.) Pursh

Occasional, deciduous woods.

* Smilacina racemosa (L.) Desf.

occasional, deciduous woods

Smilacina stellata (L.) Desf.

occasional, islands in the marsh and granite outcrop. Also along the rallway.

Smilax herbacea $L$.

Rare, Bells 1 sland.

Streptopus roseus Michx.

Rare, deciduous woods on east side.

* Trillium erectum $L$.

Common, deciduous woods.

* Trillium grandiflorum (Michx.) Salisb.

Common, declduous woods, mostly sugar Maple dominated.

Uvularia grandiflora Sm.

occasional, wooded areas.

* Uvularia sessilifolia L.

Rare, North Woods.

\section{IRIDACEAE}

$I$ Iris pseudacorus $L$.

Rare, edge of marsh near rallway

Iris versicolor $L$.

Rare, main marsh edges

Sisyrinchium montanum Greene

occasional, meadows and marsh edges. 


\section{ORCHIDACEAE}

*I Epipactis helleborine (L.) Crantz

Occasional, wooded areas.

Platanthera hyperborea L.

Rare, edge of spring near the Fingers.

\section{SALICACEAE}

Populus balsamifera L.

Common, wood at north end.

Populus deltoides Marsh.

Common, shores and disturbed places.

* Populus grandidentata Michx.

Common, woods at north end and granite outcrops.

Populus tremuloides Michx.

Common, especially at north end.

* Salix bebbiana Sarg.

Rare, marsh.

* Salix discolor Muhl.

Rare, marsh edge.

*I Salix fragilis L.

Occasional, shores of lower river.

* Salix nigra L.

Occasional, shores of lower river.

* Salix petiolaris Sm.

Rare, marsh edge.

\section{JUGLANDACEAE}

* Carya cordiformis (Wang.) K. Koch

occasional, wooded areas.

* Carya ovata (Mill.) K. Koch

Common, both granitic \& limestone outcrops.

Juglans clnerea L.

Rare, along limestone outcrop on east side.

\section{BETULACEAE}

Alnus rugosa (Du Ro1) Spreng.

Occasional, around springs on marsh edges.

Betula lutea Michx. f. (B. allegheniensis)

occasional, wooded areas.

Betula papyrifera Marsh.

Occasional, especially in wood at north end and on granite outcrops.

* Carpinus caroliniana Walt.

Common, wooded areas throughout.

Corylus cornuta Marsh

Occasional, wooded areas in dry places, mostly under oak.

* Ostrya viginiana (Mill.) K. Koch

Common, wooded areas throughout.

\section{FAGACEAE}

Fagus grandifolla Ehrh.

Common, wooded areas throughout.

* Quercus alba L.

Common, dry woods and outcrops.

* Quercus borealis Michx. f.

Common, dominant in some dry woods around the marsh, and on islands and outcrops. 
* Quercus macrocarpa Michx.

Common, limestone escarpments and islands and promontories in the marsh.

* Quercus muhlenbergi1 Engelm.

Rare, four trees on top of limestone outcrop south of Hwy. 401.

\section{ULMACEAE}

* Ulmus americana L.

Common, molst wooded areas.

vimus rubra Muhl.

Occasional, mostly on the west limestone outcrop.

URTICACEAE

Boehmeria cylindrica (L.) Sw.

Rare, moist woods.

Laportea canadensis (L.) Wedd.

Rare, depression in North Woods.

Parletaria pensylvanica Muhl.

Rare, moist woods and slopes near the Fingers.

Pilea pumila (L.) Gray

Rare, moist woods on east side north of quarry.

Urtica diolca L. ssp. diolca

Occasional, marsh edges.

*I Urtica dioica L. ssp. procera Wedd.

Common, marsh edges and disturbed open areas.

SANTALACEAE

Comandra umbellata (L.) Nutt.

occasional, granite ridges and the islands.

\section{ARISTOLOCHIACEAE}

* Asarum canadense L.

Common, in deciduous woods over limestone on either side of the lower river.

\section{POLYGONACEAE}

I Fagopyrum esculentum Moench

Rare, along the railway.

Polygonum aviculare L.

Common, disturbed open ground.

* Polygonum amphibium L. var. emersum Michx. Occasional, edges of the marsh.

*I Polygonum convolvulus L. Rare, along the railway.

^I Polygonum cuspidatum Sieb.

Rare, slope of gravel pit on east side.

* Polygonum douglasii Greene

Rare, on dry granite ridge on west side of upper cataraqui River.

Polygonum hydropiper L.

Rare, low wet areas on east side.

* Polygonum lapathifolium L.

Occasional, shorelines.

I Polygonum persicaria L.

Rare, open wet ground.

* Polygonum punctatum Ell.

Rare, moist depressions in North and Northwest woods. 
* Polygonum sagittatum L.

Occasional, moist woodland edges.

*I Rumex acetosella L.

Occasional, dry granite ridge tops and the islands.

I Rumex crispus L.

Common, wet meadows and disturbed open ground.

Rumex orbiculatus Gray

occasional, in cattail marsh.

\section{CHENOPODIACEAE}

Atriplex prostrata Buch. (A. hastata)

Rare, disturbed, open ground

Atriplex patula L.

Rare, disturbed open ground.

I Chenopodium album L.

Occasional, disturbed open ground.

I Chenopodium glaucum L.

Rare, disturbed open ground.

Chenopodium hybridum L.

occasional, in deciduous woods over limestone

I Salsola kall L. var. tenuifolia G.F.W. Meyer

Rare, along the rallway.

I Amaranthus retroflexus L.

Rare, pasture in northeast sector.

\section{PORTULACACEAE}

* Claytonia caroliniana Michx.

Common, wooded areas.

* Claytonia virginica L.

Common, wooded areas.

I Portulaca oleracea L.

Rare, weedy shore west of Bells Island.

\section{CARYOPHYLLACEAE}

I Arenaria serpyllifolia L.

occasional, gravelly open ground.

Cerastium nutans Raf.

Rare, dry limestone area on east side.

I Cerastium vulgatum L.

Common, pasture and disturbed open ground.

I Dianthus armeria L.

Rare, pastures.

* Moehringia lateriflora (L.) Fenzl. (Arenaria lateriflora)

Common, woods and thickets.

I Saponaria officinalis L.

Occasional, along the rallway and gravel pit slopes.

silene antirrhina L.

Rare, disturbed open ground.

I silene cucubalus wibel

Occasional, pasture and open ground.

I silene pratensis (Raf.) Godron and Gren. (Lychnis alba)

Rare, along the rallway.

* Stellaria calycantha (Ledeb.) Bongard

Rare, Hawthorns on west side. 
I Stellaria graminea L.

Rare, pasture at north end.

I stellaria media (L.) Cyrillo

Occasional, disturbed open ground.

CERATOPHYLLACEAE

* Ceratophyllum demersum L.

Common, in water to $2 \mathrm{~m}$ deep.

\section{NYMPHAEACEAE}

Nuphar variegatum Engelm.

Common, water to $1 \mathrm{~m}$ deep and deeper marsh

* Nymphaea tuberosa Paine

Common, water to $2 \mathrm{~m}$ deep.

\section{RANUNCULACEAE}

Actaea alba (L.) Mill.

occasional, wooded areas.

* Actaea rubra (Ait.) willd.

Occasional, wooded areas.

* Anemone canadensis L.

Occasional, marsh edges.

* Anemone quinquefolia L.

Rare, on islands in the marsh under Red Oak.

* Anemone virginiana L.

Occasional, marsh edges.

Aquilegia canadensis $\mathrm{L}$.

Occasional, granite ridges and west limestone outcrop.

I Aquilegia vulgaris L.

Rare, persisting south of Barkers Point.

* Caltha palustris L.

Rare, boggy depression near the Fingers.

clematis virginiana L.

Rare, moist woods near the Fingers.

Hepatica acutiloba DC.

Occasional, deciduous woods on east side.

Hepatica americana (DC.) Ker.

Occasional, grantte outcrops and dry crests of 1slands.

* Ranunculus abortivus L.

Common, deciduous woods.

*I Ranunculus acris L.

Common, pastures and open places.

* Ranunculus longirostris Godr.

Common, in shallow water around edge of marsh.

* Ranunculus pensylvanicus L.

Occasional, marsh edges.

Ranunculus sceleratus L.

Occastonal, ditches and shores.

Thalictrum dioicum L.

Common, deciduous woods.

Thalictum polygamum Muhl.

occastonal, marsh edges and wet meadow. 


\section{BERBERIDACEAE}

\section{Berber1s thunberg11 DC.}

Rare, pasture north of Barkers Point.

«I Berberis vulgaris L.

Occasional, pastures and open woods.

* Caulophyllum thalictroides (L.) Michx.

Occasional, woods on east side and North Woods.

* Jeffersonta diphylla (L.) Pers.

Rare, limestone talus slope on west side and on a far western island in the marsh.

* Podophyllum peltatum L.

occasional, open woods.

\section{PAPAVERACEAE}

I Chelidonium majus L.

Occasional, deciduous woods on east side.

* Sanguinaria canadensis L.

Occasional, deciduous woods on west side, Bells Island, and along the railway.

\section{FUMARIACEAE}

* Corydalis aurea willd.

Rare, along the rallway north of Hwy. 401.

* Corydalis sempervirens (L.) Pers.

Rare, granite outcrop on west side of upper river.

Dicentra canadensis (Goldie) Walp.

Rare, deciduous woods over shallow limestone near Barkers Point. Dicentra cucullarla (L.) Bernh.

Rare, deciduous woods over limestone outcrop on east side.

\section{BRASSICACEAE}

I Alliaria petiolata (Bleb.) Cavara \& Grande (A. officinalis) Common, on slopes of limestone outcrops.

* Arabis divaricarpa A. Nels.

Occasional, open diciduous woods on east side and granite outcrops.

I Barbarea vulgaris R. Br.

Occasional, meadows and pastures.

I Berteroa incana (L.) DC.

Rare, along the rallway.

I Capsella bursa-pastoris (L.) Medic.

Occasional, pastures and meadows.

Dentaria diphylla Michx.

Occasional, Sugar Maple woods over limestone.

Dentaria laciniata Muhl.

Occasional, Sugar Maple woods over limestone.

* Dentaria $x$ maxima Nutt.

Rare, limestone talus under sugar Maple on east side.

* Descurania pinnata (Walt.) Britt. var. brachycarpa (Richards.) Fern. Rare, in gravel along the rallway.

I Diplotaxis tenuifolia (L.) DC.

Occasional, in gravel along the railway.

I Erucastrum gallicum (Willd.) O.E. Schulz

Rare, along the rallway.

I Erysimum cheirantholdes L.

Rare, disturbed open ground. 
I Erysimum hieracifolium L.

Rare, open disturbed area near railway at north end of west granite outcrop, and along west shore of Bells Island.

I Hesperis matronalis L.

Common, moist woods.

I Lepidium densiflorum Schrader

Rare, open gravelly ground.

*I Nasturtium offlcinale $\mathrm{R}$. Br.

Rare, springs beside railway in main marsh.

Rorippa islandica (Oeder) Borbas var. hispida (Desv.) Butters and Abbe Rare, shore west of Bells Island.

I Sinapis arvensis L. (Brassica kaber)

Rare, weedy shore west of Bells Island.

I sysimbrium officinale (L.) Scop.

Rare, open disturbed woods south of Barkers Point.

I Thlaspi arvense L.

Rare, pastures.

I Thlaspl perfollatum L.

Rare, pasture north of Barkers Point.

\section{CRASSULACEAE}

Penthorum sedoides L.

Occasional, seasonally wet open ground.

*I Sedum acre L.

Rare, on west granite outcrop at north end.

*I Sedum telephium L.

Rare, on west granite outcrop at north end.

\section{SAXIFRAGACEAE}

Mitella diphylla L.

Rare, moist limestone talus on east side near the Fingers.

* Ribes americanum Mill.

Occasional, deciduous woods on talus of east limestone outcrop.

* Ribes cynosbat1 L.

Occasional, wooded areas.

Ribes hirtellum Michx.

Occasional, wooded areas.

*I Ribes sativum syme

Rare, established in Barkers Point Area.

* Saxifraga virginiensis Michx.

Occasional, open areas on granite ridges

Tiarella cordifolia L.

Occasional, deciduous woodland

HAMAMELIDACEAE

Hamamelis virginiana L.

Rare, dry open woods at north end.

ROSACEAE

Agrimonia gryposepala wallr.

Occasional, deciduous woods on east side.

Amelanchier alnifolla Nutt. var. compacta (Nielsen) McKay

Rare, granitic ridge and Bells Island.

* Amelanchier arborea (Michx. f.) Fern. ssp. arborea

occasional, deciduous woods. 
* Amelanchler sanguinea (Pursh.) DC. var. sanguinea

occasional, edges of woods and clearing.

* Aronia prunifolia (Marsh) Rehder

Rare, boggy depression near the Fingers.

* Crataegus brainerdil Sarg.

Rare, found only along the rallway south of hwy. 401.

* Crataegus chrysocarpa Ashe

Common, throughout in woods, fencerows, and pastures.

* Crataegus chrysocarpa Ashe var. aboriginum (Sarg.) Kruschke

status uncertain, old field at $\mathbf{8 2 3 0 2 5 .}$

* Crataegus chrysocarpa Ashe var. phoenica Palmer

Status uncertain, along railway on west side.

* Crataegus flabellata (Bosc. ex Spach.) K. Koch

occasional, south end of main marsh area on the east side.

* Crataegus macrantha Lodd.

Common, throughout in woods, fencerows and pastures.

* Crataegus pedicellata Sarg.

occasional, east side of old ferry trail near hwy. 401 and on east side of marsh.

* Crataegus punctata Jacq.

Common, especially on west side of marsh.

* Crataegus submolils Sarg.

Common, on granite outcrops and along the east limestone outcrop.

* Fragaria virginiana Duchesne

Common, open meadows, pasture and open ground.

* Geum canadense Jacq.

Common, deciduous woods.

Potentilla anserina L.

Rare, east shore near Barkers Point.

*I Potentilla intermedia L.

Common, dry open ground.

* Potentilla norvegica L.

Occasional, dry open ground.

* Potentilla palustris (L.) Scop.

occastonal, main marsh.

*I Potentilla recta L.

Occasional, dry open ground.

* Potentilla simplex Michx.

occastonal, dry open ground.

*I Prunus interstitia L.

Rare, Bells Island and around fields.

Prunus nigra Ait.

Rare, deciduous woodland edge near the quarry.

Prunus pensylvanica L.f.

Rare, deciduous and mixed wood.

Prunus serotina Ehrh.

Common, deciduous woods.

Prunus virginiana L.

Common, deciduous woods.

I Pyrus malus L.

Rare, Barkers Point.

* Rosa acicularis Lindl.

Rare, along the railway banks.

Rosa blanda Ait.

Occasional, on islands in the marsh and dry slopes. 
*I Rosa multiflora Thunb.

Rare, but locally frequent in pasture area north of Barkers Point.

*I Rosa rubrifolia Vill.

Rare, pasture north of Barkers Point.

* Rubus alleghentensis Porter

Common, open woods.

* Rubus flagellaris L.

Rare, open places on west granitic outcrop. Few plants flowered, but those that did were more like R. flagellaris than R. arundelanus.

* Rubus odoratus $L$. Occastonal, open woods.

* Rubus strigosus Michx. Occastonal, open woods.

Spiraea alba Du Roi Common, wet meadows and marsh edges.

Waldsteinia fragarioides (Michx.) Tratt. Common, dry open wooded areas.

\section{FABACEAE}

* Amphicarpa bracteata (L.) Fern. var. comosa (L.) Fern. Edges of Typha marsh on west side of river north of Hwy 401 bridge. The status of this and the typical variety in the area is uncertain.

I Coronilla varia $L$. Rare, beside Hwy. 401.

* Lathyrus palustris $L$. Common, marsh.

Lespedeza hirta (L.) Hornem. Rare, along the rallway.

I Lotus corniculatus $L$. Occastonal, disturbed open ground and pastures.

$I$ Medicago lupulina $L$. Common, disturbed open ground.

I Medicago sativa $L$. Rare, pasture at $N E$ corner.

I Melilotus alba Desr. Common, disturbed open ground.

I Melilotus officinalis ( $L$.$) Desr.$ occasional, disturbed open ground.

*I Trifolium aureum Pollich (T. agrarium) occasional, dry crests of islands in the marsh and west granite outcrop.

I Trifolium hybridum $L$. Occasional, pasture at north end.

I Trifolium pratense $L$. Common, disturbed open ground and pastures.

I Trifolium repens $L$. Common, disturbed open ground and pasture.

Vicia cracca $L$. Common, open disturbed ground, meadows and marsh edges.

*I vicia tetrasperma (L.) Moench. Rare, dry open meadows near islands at north end on east side. 


\section{GERAN IACEAE}

* Gerantum maculatum L.

Common, deciduous woods.

Gerantum robertianum L.

common, rocky slopes on both granite and limestone outcrops.

\section{RUTACEAE}

Zanthoxylum americanum Mill.

Common, thickets and woodland edges on clay or limestone.

\section{POLYGALACEAE}

Polygala pauciflora willd.

Rare, west granite outcrop.

* Polygala senega L.

Rare, base of west limestone outcrop along railway bank.

\section{EUPHORBIACEAE}

\section{* Acalypha rhomboidea Raf.}

Rare, moist mucky depression in the Fingers area.

I Euphorbia cyparissias L.

Rare, along the railway.

\section{ANACARDIACEAE}

* Rhus aromatica Ait.

Rare, Bells Is land and granite ridge.

Rhus radicans L. var. rydberg11 (Small) Rehder

occasional, along the railway.

* Rhus typhina L.

Common, edges of woods and old pasture.

\section{AQUIFOLIACEAE}

* Ilex verticillata (L.) Gray

Occasional, mucky depression in NW woods, marsh edges and bogy pocket near the Fingers.

\section{CELASTRACEAE}

Celastrus scandens $\mathrm{L}$.

Occasional, exposed slopes of limestone outcrops and along the railway.

\section{STAPHYLEACEAE}

* staphylea trifoliata L.

Occasional, talus slopes of limestone outcrops.

\section{ACERACEAE}

I Acer negundo L.

Common, disturbed areas, shores of lower river.

Acer nigrum Michx. f.

Comon, along east limestone outcrop.

Acer rubrum L.

Occasional, mostly on granite outcrops.

Acer saccharum Marsh

Common, wooded areas, dominant in the deciduous woods along the limestone outcrops.

* Acer spicatum Lam.

Rare, limestone talus in the Fingers area. 
BALSAMINACEAE

Impatiens biflora Walt.

Common, marsh, wet meadows and wet wooded areas.

* Impatiens pallida Nutt.

Rare, wooded Iimestone talus near the Fingers.

\section{RHAMNACEAE}

Ceanothus americanus $L$.

Rare, an island on west side of the river.

*I Rhamnus catharticus $L$. Common, disturbed wooded areas.

I Rhamnus Erangula $L$. Rare, disturbed wooded area south of Barkers Polnt.

\section{VITACEAE}

Parthenocissus quinquefolia (L.) Planch. Common, woodland edges and clearings.

Vitis riparia Michx. Common, woodland edges and clearings.

\section{TILIACEAE}

Tilla americana $L$.

Common, deciduous woods and along the base of granite outcrops beside the upper river.

\section{MALVACEAE}

*I Abutilon theophrasti Medic.

Rare, on dredge heap below the locks.

I Malva moschata $L$.

Rare, open gravelly soll at the limestone quarry.

I Malva neglecta Wallr.

Rare, disturbed open ground near Barkers Point.

\section{HYPERICACEAE}

$I$ Hypericum perforatum $L$.

Common, pastures and disturbed open ground.

* Hypericum punctatum Lam.

occasional, thickets and woods on islands and promontortes.

\section{VIOLACEAE}

Viola canadensis $L$.

Rare, deciduous woods on east side near quarry.

* Viola conspersa Reichenb.

Occasional, molst open woods.

* Viola papilionacea Pursh

occasional, moist open woods.

Viola pubescens Ait.

occasional, deciduous woods.

* Viola septentrionalis Greene Occasional, Bells Island and islands in the marsh.

* Viola sororia willd. occasional, deciduous woods over limestone. 


\section{ELAEAGNACEAE}

* Shepherdia canadensis (L.) Nutt.

Rare, edge of North Woods and along eastern limestone outcrop.

\section{LYTHRACEAE}

I Lythrum salicaria L.

common, inner marsh edges and wet meadows.

\section{ONAGRACEAE}

* Circaea quadrisulcata (Maxim.) Franch. \& Sav.

Rare, deciduous woods below east limestone outcrop.

* Epilobium glandulosum Lehm.

In the marsh, status uncertain.

I Epilobium hirsutum L.

Occasional, drier edges of the marsh.

Ludwigia palustris (L.) Ell.

Rare, marsh.

Denothera biennis L.

Occasional, disturbed open ground.

cenothera parviflora L.

Rare, disturbed open ground.

\section{HALORAGIDACEAE}

* Myriophyllum exalbescens Fern.

Occasional, marsh channels and south of main marsh in water to $2 \mathrm{~m}$ deep.

*I Myriophyllum spicatum L.

Common, throughout the Cataraqui River in water to $2 \mathrm{~m}$ deep. Not known in the Kingston region in 1970 (Beschel et al.. 1970).

\section{ARALIACEAE}

* Aralia hispida Vent.

Rare, in open areas at south end of west granite outcrop.

Aralla nudicaulis L.

Rare, wooded area on west granite outcrop.

Aralla racemosa L.

Rare, moist wooded slope on east granite outcrop.

APIACEAE

Cicuta bulbifera L. Common, marsh.

Cicuta maculata L.

Occasional, marsh.

Cyptotaenia canadensis (L.) DC.

Occasional, deciduous woods on east side.

I Daucus carota L.

Common, disturbed open ground.

Heracleum lanatum Michx.

Rare, edge of molst pasture north of the Fingers and Bells Island. Osmorhiza claytoni (Michx.) Clarke

Occasional, deciduous woods over limestone.

osmorhiza longistylis (Torr.) DC.

Occasional, deciduous woods over limestone.

I Pastinaca sativa L.

Occasional, pasture at north end and along railway and Bells Island. 
* Sanicula marilandica L.

Rare, low woods in the Fingers area.

* Sium suave Walt.

Occasional, marsh.

* Taenidia integerrima (L.) Drude

Occasional, granite ridge, east limestone outcrop and Bells Island.

CORNACEAE

Cornus alternifolia L.f.

Occasional, deciduous woods.

* Cornus obliqua Raf. (C. amomum ssp. obliqua)

Common, woodland edges of marsh and old fields.

* Cornus racemosa Lam.

Common, open limestone outcrops, islands and old fields.

* Cornus stolonifera Michx.

Occasional, woodland edges of the marsh.

\section{ERICACEAE}

* Arctostaphylos uva-ursi (L.) Spreng.

Rare, only on high open top of west granite outcrop at north end.

Gaultherla procumbens L.

Occasional, granite outcrops and higher islands.

* Monotropa uniflora L.

Rare, under oak on west granite outcrop.

Pyrola elliptica Nutt.

Rare, granite outcrops and wooded slope near the Fingers.

* Vaccinium angustifolium Ait.

Common, dry tops of granite outcrops and higher crests of islands and promontories.

\section{PRIMULACEAE}

Lysimachia ciliata L.

Common, wooded areas and woodland edges.

I Lysimachia nummularia L.

Occasional, wet woods on east side and at north end.

* Naumbergia thyrsiflora (L.) Duby

Common, marsh.

\section{OLEACEAE}

* Fraxinus americana L.

Common, wooded areas throughout.

* Fraxinus nigra Marsh

Rare, boggy depression in the Fingers area.

Fraxinus pennsylvanica Marsh

Rare, low woods in the Fingers area and at north end.

*I Ligustrum vulgare L.

Rare, persisting long after cultivation south of Barkers Point.

I syringa vulgaris L.

Rare, persisting and spreading south of Barkers Point, and at the north end of the west granite ridge.

GENTIANACEAE

* Menyanthes trifoliata L.

Rare, in the main marsh on floating sedge mats. 
APOCYNACEAE

* Apocynum androsaemtfollum L.

Rare, on west granite outcrop and along the rallway.

\section{ASCLEPIADACEAE}

Asclepias incarnata L.

Common, marshes and wet meadows.

* Asclepias syriaca L.

common, open disturbed areas and pastures.

\section{CONVOLVULACEAE}

I Convolvulus arvensis L.

Rare, along the railway.

* Convolvulus sepium L.

Common, marsh edges and wet meadows.

* Cuscuta gronovil willd.

occasional, on marsh vegetation.

\section{POLEMONIACEAE}

Phlox divaricata L.

Rare, deciduous woods over limestone on east side.

\section{HYDROPHYLLACEAE}

Hydrophyllum virginianum L.

occasional, deciduous woodlands.

\section{BORAGINACEAE}

I Cynoglossum officinale L.

Occasional, disturbed woods on east side.

I Echlum vulgare L.

Comon, open disturbed areas.

I Lithospermum officinale L.

Occasional, pasture at north end.

VERBENACEAE

Verbena hastata L.

Common, Bluejoint marsh.

Verbena urticifolia L.

Common, Bluejoint marsh and woodland edges.

\section{LAMIACEAE}

* I Glecoma hederacea L.

Occasional, disturbed open woods.

* Hedeoma hispida Pursh

Rare, disturbed open ground near quarry.

* I Leonurus cardiaca L.

Common, disturbed open areas.

Lycopus americanus Muhl.

Conmon, marsh.

Lycopus untflorus Michx.

Common, marsh.

Mentha arvensis L.

occasional, marsh and marsh edges. 
I Nepeta cataria L. Common, disturbed open ground.

* Prunella vulgaris L. Common, moist open woods and clearing throughout.

saturefa vulgaris (L.) Fritsch. occasional, open disturbed ground.

scutellaria galericulata L. Common, marsh.

Scutellaria lateriflora L. Common, marsh.

* stachys tenuifolia Willd. occasional wet meadows and marsh edges.

Teucrium canadense L. Occasional, wet meadows and marsh edges.

\section{SOLANACEAE}

*I Solanum dulcamara L. Common, marsh, swampy woods and open limestone talus.

I Physalis alkekengl L. Rare, disturbed ground below the quarry.

\section{SCROPHULARIACEAE}

I Chaenorrhinum minus (L.) Lange Common, disturbed open ground in limestone gravel.

I Linaria vulgaris Hill Common, open disturbed areas. Melampyrum lineare Desr. Rare, under pine and oak on west granite outcrop. Mimulus ringens $\mathrm{L}$. Common, wet meadows and marsh.

Penstemon hirsutus (L.) Willd. Occasional, dry open ground, pastures and islands.

* Scrophularia lanceolata Pursh Common, woods and thickets.

I Verbascum thapsus L. Occasional, disturbed open ground.

I Veronica anagallis-aquatica L. Occasional, springs along the western edge of the marsh.

I Veronica officinalis $\mathrm{L}$. Occasional, dry woods. Veronica peregrina L. Occasional, dry, open pasture and top of west granite outcrop.

OROBANCHACEAE

Epifagus virginiana (L.) Bart.

Rare, under Beech trees in Northwest woods and on east limestone outcrop near the quarry.

\section{LENT IBULAR IACEAE}

Utricularia gibba L.

Rare, edges of marsh pool.

* Utricularia intermedia Hayne

Rare, in main Typha marsh in middle of southern section. 
* Utricularia minor L.

Rare, in Typha marsh in middle of southern section.

* Utricularia vulgaris L.

Common, mostly in the marsh channels.

PHRYMACEAE

Phryma leptostachya L.

Rare, deciduous woods on east side north of quarry.

\section{PLATAGINACEAE}

I Plantago lanceolata L.

Common, disturbed open ground.

I Plantago major L.

Common, disturbed open ground, and on limestone shores on east side.

Plantago rugeli1 Decne.

Common, disturbed open ground.

\section{RUBIACEAE}

* Cephalanthus occidentalis L.

Rare, in a spikerush marsh on the west side of the river above Hwy 401 bridge.

Gallum aparine L.

Occasional, deciduous woods.

* Galium tinctorium L.

Marsh and marsh edges, status uncertain.

* Galium palustre L.

Marsh and marsh edges, status uncertain.

Mitchella repens L.

Rare, dry woods under Pine near the Fingers.

\section{CAPRIFOLIACEAE}

Diervilla lonicera Mill.

Common dry slopes and outcrops in more or less open locations.

I Lonicera $X$ bella Zab.

Rare, disturbed open ground.

Lonicera canadensis Marsh

Rare, deciduous woods north of the quarry.

* Lonicera diolca L.

Occasional, Bells island and islands in the marsh and west granite outcrop.

* Lonicera tatatica L.

Occasional, disturbed areas.

* Sambucus canadensis L.

Occasional, wooded areas.

* Sambucus pubens Michx.

Occasional, wooded areas.

symphorlcarpos albus (L.) Blake

Common, dry rocky slopes of west limestone outcrop and the granite outcrops.

Virburnum acerifolium L.

Common, wooded areas.

^I Viburnum lantana L.

Rare, Bells Island. 
* Viburnum lentago L.

Common, islands, woodland edges and thickets.

* Viburnum rafinesquianum Schultes

Common, dry open oak woods, islands, promontories and granite outcrop.

VALERIANACEAE

* I Valeriana officinalis L.

Spreading after cultivation south of Barkers Point.

\section{DIPSACACEAE}

I Dipsacus sylvestris Huds.

Rare, pasture at north end.

\section{CUCURBITACEAE}

Echinocystis lobata (Michx) T.\& G.

Rare, along the shore west of Bells Island.

\section{CAMPANULACEAE}

Campanula aparinoldes Pursh var. grandiflora Holz.

Common, marsh.

I Campanula rapunculoides L.

Occasional, wooded slopes on east and west limestone outcrop.

Campanula rotundifolia L.

Rare, limestone boulders near the Fingers.

\section{LOBELIACEAE}

* Lobelia inflata L.

Occasional, granite outcrops.

Lobelia siphilitica L.

Occasional, woodland edges of marsh.

\section{ASTERACEAE}

Achillea millefolium L.

Common, open disturbed ground.

*I Ambrosia artemesilfolla L.

Common, open disturbed ground.

Anaphalis margaritacea (L.) Benth. \& Hook.

Rare, granite outcrops at north end.

* Antennarla neglecta Greene var. rand11 (Fern.) Cronq.

Occasional, dry promontories and shoreline banks.

I Arctium minus (H1ll) Bernh.

Common, disturbed open ground.

I Artemesia biennis willd.

Rare, along the rallway.

*I Artemesia vulgaris L.

Rare, meadow on shore north of Bells Island.

Aster cordifolius L.

Common, pastures and drier meadows.

* Aster ericoides L.

Rare, meadow along shore north of Bells Island.

Aster lanceolatus willd.

Common, wet meadows

Aster lateriflorus (L.) Britt.

Common, marsh and marsh edges. 
Aster macrophyllus L.

Common, especially in wooded areas of the granite outcrops at the north end.

Aster novae-angliae L.

common, fields, pastures, edge of railway.

Aster puniceus L.

Common, swampy areas and marsh edges.

Aster umbellatus Mill.

Rare, marsh edge near the Fingers.

* Bidens becki1 Torr. (Megalodonta becki1)

In water 1-2 $\mathrm{m}$ deep on the west side of the main channel near the upper marsh channel.

Bidens cernua L.

Common, cattail marsh.

Bidens frondosa L.

common, cattail marsh.

I Chrysanthemum leucanthemum L.

Common, open, often disturbed places.

I Cichorium intybus L.

Occasional, open gravelly places.

I Cirstum arvense (L.) Scop.

Common, fields, pastures and open places.

I Cirstum vulgare (Savi) Tenore

Common, fields, marshes, open places and wet meadows.

Conyza canadensis (L.) cronq.

common, disturbed open ground.

* Erechtites hieracifolia (L.) Raf.

Rare, disturbed woods on east side near the quarry.

Erigeron annuus (L.) Pers.

Common, disturbed open ground.

Erigeron philadelphicus L.

Common, disturbed open ground.

Erigeron strigosus Muhl.

Common, disturbed open ground and wooded areas.

Eupatorium maculatum L.

Common, marsh.

Eupatorium perfoliatum. L.

Common, marsh.

Eupatorium rugosum Houtt.

Rare, deciduous woods near quarry on east limestone outcrop.

Helianthus divaricatus L.

Rare, on west granite ridge and at south end of west limestone outcrop.

I Hieracium aurantiacum L.

Common, disturbed open ground, pastures.

*I Hieractum florentinum All.

Common, disturbed open ground.

* I Inula helentum L.

Rare, pasture at north end

Lactuca biennis (Moench) Fern.

occasional, wooded areas.

Lactuca canadensis $\mathrm{L}$.

occasional, wooded areas.

* I Lapsana communis L.

Common, woods along east limestone outcrop. 
*I Onopordum acanthium L.

Rare, in a stony area around a farm near Barkers Point.

* Prenanthes alba L.

Occasional, wooded areas.

Prenanthes altissima L.

Occasional, wooded areas.

Rudbeckia hirta L.

Rare, pasture at north end and along the railway.

* Solldago caesia L.

Common, especially abundant in wooded parts of the granite outcrops.

solidago canadensis L.

Common, marsh edges, pastures and meadows.

Solidago flexicaulis L.

Common, Sugar Maple woodlands.

Solidago gigantea Alt.

Rare, meadow along shore north of Bells Island.

solidago graminifolia (L.) Salisb.

Common, Bluejoint marsh.

Solidago hispida Muhl.

Common, granite rock outcrops at north end and on dry places on some of the 1slands in the marsh.

* Solidago funcea Ait.

Common, dry crest of islands, granite and limestone outcrops and promontories.

Solidago nemoralis Ait.

Common, drier open locations throughout.

Solidago rugosa Mill.

occasional, moist wooded areas.

I Sonchus arvensis L.

Rare, disturbed open ground along railway.

I Tanacetum vulgare $\mathrm{L}$.

Occasional, disturbed open ground.

*I Taraxacum officinale Weber

Common, deciduous woods and disturbed open ground and pastures throughout.

*I Tragopogon dubius Scop.

Rare, disturbed open ground along railway.

I Tussilago farfara L.

Rare, clay bank on east side. 


\section{PHYTOGEOGRAPHY}

Although the Cataraqui Marsh area contains relatively few species that are disjunct or near their distribution limits, it does include species exemplifying 5 interesting phytogeographic patterns.

Perhaps the most interesting element in the regional flora (involving approximately 30 species and many plants that are rare in ontario) is the southern element which reaches its northern limits (both in ontario and overall) in the Kingston area (Fox and Soper 1954; Soper, 1955, 1962; Cody, 1982). A good example from the Cataraqui Marsh area is the Chestnut Oak (Quercus muhlenbergi1). Rare in Ontario, this species has a southern and midwestern total distribution (Fig. 4). In addition there are Jeffersonia diphylla, Teucrium canadense and stachys tenuifolia. Other predominantly southern species occurring in the Cataraqui Marsh area extend north and reach their distributional limits in the Ottawa valley. Included here are Asarum canadense, Carya ovata, Carya cordiformis, Dentaria laciniata, Hamamelis virginiana, Juglans cinerea, Juniperus virginiana, Najas guadalupensis, Heteranthera dubia, staphylea trifoliata and Taenidia integerrima.

some of the southern species are also western, and a western and midwestern element is present in the Kingston region, and generally in eastern Ontario. Species of this western category in the Cataraqui Marsh area extend east of Kingston but some do not extend far east. Examples include Rhus aromatica, Polygonum douglasil, and the uncommon aquatic Alisma gramineum (Big. 6).

A number of plants occurring in the Kingston area are characteristic of the Appalachian Mountains region of the United states. One of the most unusual plants in the Cataraqui Marsh area, Juncus secundus, provides a good example of this group (Fig. 5). Another is Crataegus brainerdil.

Within southern Ontario, the distributions of some plants are strikingly correlated with rock type. Since the Cataraqui Marsh area has both acid granite rock and alkaline calcareous limestone rocks, it is not surprising that it includes plants characteristic of both rock types. Examples of plants confined to granite rocks are woodsia ilvensis and corydalis sempervirens. Cystopteris bulbifera, Corydalis aurea and Dryopteris goldiana are characteristic of limestone rocks. 


\section{DIVERSITY}

Diversity is an important consideration in the protection of natural areas since it not only enhances recreational opportunities connected to natural history but it also relates to protecting the maximum number of components within a given region. Furthermore, floristic diversity is often correlated with faunal diversity.

The Cataraqui area has an unusual diversity of vascular plants in general. It includes 472 native and 153 introduced species for a total of 625. This is undoubtedly a result of both the variety of habitats (woods, meadows, marsh, etc.) and the variety of substrates (acid rock, limestone rock, acid and alkaline soil and water of varying turbidity and chemistry), and the variety of exposures (north, south, etc.).

There are few areas of less than $10.0 \mathrm{~km}^{2}$ (approx. $4 \mathrm{mi}^{2}$ ) which contain over 600 species. The number of plants in the Cataraqui Marsh area is over $1 / 3$ of the total number of plants found in the central Kingston region (Beschel, 1970), and in terms of native species, it is more than occur in some townships of eastern ontario.

The diversity of aquatic vascular plants in Cataraqui Marsh was compared with other similar (nutrient-rich, calcareous, alkaline) Great Lakes marshes. In order to achieve the most reliable comparison, difficult groups which may be overlooked or omitted (e.g. Carex, Eleocharis, Scirpus) in some studies, are not included. Despite this, the index includes most true aquatics found in the open water areas of southern ontario cattail marshes, and it is believed to be a relatively reliable index of floristic diversity. It is clear from the comparison that Cataraqui Marsh is unusually rich in aquatics. with 51 species recorded (Table 2), it is more diverse than the 5 other Great Lakes marshes for which information is currently available. This is surprising since some of the other marshes are in regions of generally more diverse and unusual vegetation.

This level of aquatic plant diversity is impressive, not only for southern ontario, but also for a much broader region. For example Forest (1977) had a maximum of 12 species of pondweds in lakes and bays (of similar water chemistry) in New York state.

The marsh vegetation (developing on permanently damp but not permanently inundated substrate) is also diverse, but there is not much data on the composition of southern ontario cattail marshes of this type with which to compare 1t. Although predominantly a Cattail (Typha spp.) and Bluejoint (Calamagrostis canadensis) marsh, the actual number of plants that occur characteristically ( $1 . \underline{.}$. . not accidentally) in these associations in the area is at least 80 , so that the marshes are much richer than a first impression would suggest. 


\section{SIGNIFICANT SPECIES AND COMMUNITIES}

The significant species (See "Methods" for determination) found in the Cataraqui Marsh area are shown in Table 3. Three species found in the area have been listed as nationally rare (Argus and White 1977). These are Jeffersonia diphylla, Juncus secundus and Quercus muhlenbergil. These same three as well as carex artitecta, Crataegus brainerdil, and Cinna arundinacea have been listed as provincially rare. of the provincially rare and nationally rare species, the most significant is Juncus secundus (Fig. 6). The others are less rare in the province and in Canada. An additional 6 species are provincially uncommon and 23 species are locally rare (although some in this latter group may not be as rare as the presently available information suggests). This list (Table 3) of national, provincial and regionally significant species is an impressive one, but it is not remarkable. Several areas of similar size around Kingston and many areas throughout Ontario have more impressive lists of significant vascular plant species (in terms of both the total number and the relative rarity of the species listed).

Most of the significant species present in the area occur there in relatively small numbers (Table 3). This is often the case with rare plants, and it does not necessarily imply that they are dying out. The status of a few of the regionally rare species in the area remains uncertain due to difficulty in field recognition.

often rare plants are concentrated within an area because they share unusual habitat requirements that are spatially restricted. Within the Cataraqui Marsh study area, such a concentration is not the case. Instead the significant species are widespread with never more than 2 or 3 occurring together. There is a tendency, however, for most of the significant species to be located in the more northerly section where human pressure on the landscape and habitat alteration have been much less. Most of the significant species are plants of wetlands (wet meadow, marsh and open water) and drier exposed portions of rock outcrops and islands.

No significant plant communities have been identified in the Cataraqui Marsh area. The kinds of communities present within the area are also apparently common outside it within the region. The general diversity in the region and the lack of detailed regional information on communities and plant associations make it difficult to know definitely what is significant in terms of being regionally unusual. Although the communities may not be significant with regard to their type, the wetland communities in particular appear to be significant with regard to their diverse composition (see under "Diversity"). 


\section{SIGNIFICANCE OF THE FLORA AND LOCAL FLORISTIC DIVERSITY TO WATERFOWL AND OTHER WILDLIFE}

Aquatic vegetation is the primary food of many waterfowl. Areas where certain aquatic plants are abundant represent valuable feeding grounds. It is widely considered important to ensure appropriate feeding areas for waterfowl in order to provide for hunting and for waterfowl viewing. Although less often recognized the latter sometimes represents a significant proportion of total recreational activity (Kreutzwiser, 1981).

Pondweeds (Potamogeton spp.) are the food most utilized by ducks in the eastern region of the U.S. and Canada comprising over 128 by volume of the diet (Martin and Uhler, 1939). There are 12 species of pondweeds in Cataraqui Marsh and the species most frequently recognized in duck stomachs, Potamogeton pectinatus, is locally abundant. Wild Rice (zizania sp.), Naiads (Najas flexilis), Duckweeds (Lemna spp.) and Eel-grasses (Vallisneria americana) are also very important (Moyle and Hotchkiss, 1945; Martin and Uhler, 1939; McAtee, 1939; Martin et.al.. 1961: Lamoureaux, 1970) together comprising over 148 by volume of the diet. All of these species are at least locally abundant in the marsh. In Addition water plantains (Allsma spp.), Arrowheads (Sagittaria spp.) and Bur-reed (sparganium spp.) are important food sources and are all abundant in the marsh. Bur-reed seeds in particular are reported to be a favourite food of the Mallard Duck with 1,082 of the $5 \mathrm{~mm}$ long seeds being taken from a single stomach (Mcatee, 1939).

The variety of aquatic plant foods available in the Cataraqui Marsh area (see Table 2) is advantageous since different species become available at different times so that the period of waterfowl utilization is increased. Taking into account both the abundance and diversity of waterfowl food plants in the marsh, and the size of the marsh, Cataraqui has an unusually high potential as a waterfowl feeding area.

studies have shown that increased structural variation and diversity (expressed in terms of number of different plant communities) is correlated with increased use by wildiffe (e.g. Weller, 1978). The general diversity of habitats in the Cataraqui area is impressive. However, the main marsh has been referred to as "a dense overmature stand of cattail, mostly floating, with minimal openings or diversity" (Hodges and Arbour, 1981). Quite to the contrary, the main marsh is rich in species and diverse in plant assoiciations (see under "Vegetation"). The notion that extensive cattail marshes are of limited value for wildlife is based on both the perceived increase in duck production associated with water-edge habitats and the general lack of understanding of the complexity and variation in cattail marshes. of course wildlife is not restricted to ducks. Rails, Marsh Wren, Bitterns, Blackbirds, and many other animals, and various significant plants may be disadvantaged by open water edges, and prefer marsh interiors. 


\section{ACKNOWLEDGEMENTS}

Mr. B. Tishe, Parks Canada interpreter, kindly helped with field work and particularly with the provision and operation of the boat to facilitate marsh study. Field assistance was provided by F. Beales, V.R. Brownell, I. Dobson, G. Mitrow and $w$. Wojtas. The Natural Resource Conservation Division of Parks Canada, Ontario Region, kindly provided logistical support and base maps. Specimens of Crataegus were identified by Dr. J.B. Phipps of the University of Western Ontario. 


\section{REFERENCES}

Argus, G.W. and D.J. White. 1977. The rare vascular plants of ontario. National Museum of Natural Sciences, Ottawa, Syllogeus no. 14: 63 pp.

Beschel, R.E. 1970. Toadshade and Virginia Bluebells in their habitat near Kingston. Blue Bill 17: 23-27.

Beschel, R.E., A.E. Garwood, R. Hainault, I.D. Macdonald, S.P. van der Kloet, C.H. Zavitz. 1970. List of the vascular plants of the Kingston Region. Fowler Herbarium, Queens University, Kingston. 92 pp.

Blancher, P.J. 1984. Natural resource description and management considerations, Cataraqui Marsh - Rideau Canal. Unpublished report submitted to Parks Canada. $70 \mathrm{pp}$. - appendices.

Catling, P.M. 1983. Botanical survey of the Cataraqui Marsh area. Unpublished report submitted to Parks Canada. I-III, 62 pp.

Catling, P. 1985. Notes on the vegetation of the Cataraqui Marsh area, and a request for additional information. Blue Bill (Bulletin of the Kingston Field-Naturalists), 32(1): 5-6.

Cecile, C.P. 1981. Oshawa second Marsh baseline study - interim report integration and interpretation of ecological data. $141 \mathrm{pp}$.

Crowder, A. 1979. Rare plants in the Kingston area. $11 \mathrm{pp}$.

Cody, W.J. 1982. A comparison of the northern limits of distribution of some vascular plant species found in southern ontario. Naturaliste Can., 109: 63-90.

Farney, R.A. and T.A. Bookhout. 1982. Vegetation changes in a Lake Erie Marsh (Winous Point, ottawa Co.. Ohio) during high water years. Ohio Jour. Sci., 82: 103-10.

Fox, W.S. and J.H. Soper. 1954. The distribution of some trees and shrubs of the Carolinian zone of southern ontario. Trans. Roy. Can. Inst., $30(2)$ : $99-130$.

Gleason, H.A. and A. Cronquist. 1963. Manual of Vascular plants of northeastern United States and adjacent Canada. D. Van Nostrand Co., Inc. New York. $810 \mathrm{pp}$.

Gillespie, J.E., R.E. Wicklund and B.C. Matthews. 1966. The soils of Frontenac County. Agriculture Canada, Research Branch, Report No. 39, 67 pp.

Gow, D.. P. Kelly and K. McLean. 1982. Blological Research Projects - st. Clair National Wildlife Area. $85 \mathrm{pp}$.

Hodges, J.R. 1977. Rideau waterway wetlands. Canadian Wildlife Service (portions of a report in Parks Canada library).

Hodges, J.R. and J. Arbour. 1981. The environment of the Corts Corridor The Rideau sector. addendum no. I Landscapes of the Rideau sector. Lands Directorate, Ecological Land Classification Series No. 15: 59 pp \& appendices.

Kreutzwiser, R. 1981. Recreational values of lakeshore marshes. pp. 48-57 In A. Champagne ed., Proceedings of the Ontario wetlands Conference. Federation of Ontario Naturalists, Don Mills, Ontario.

Krull, J.N. 1970. Aquatic plant macroinvertebrate associations and waterfowl J. Wildl. Manage. 34: 707-718.

Lamoureaux, W.J. 1970. Aquatic plants for Eish and wildlife. 3rd edition. Royal Botanical Gardens Technical Bulletin No. 1, Hamilton, Ontario.

Lathem, K.W. 1976. Cataraqui River Basin Floodplain management. Cataraqui Region Conservation Authority.

Little, E.L. 1971. At las of United STates Trees, volume 1. Conifers and important hardwoods, U.S. Dept. Agriculture, Forest Service, misc. publ. no. 1146: I-V, 1-9, 200 maps, - indices. 
Martin, A.C. and F.M. Uhler, 1939. Food of game ducks in the United states and Canada. United States Dept. Agric., Tech. Bull. no. 634: 156 pp.

Martin, A.R.D., H.S. Zim, and A.L. Nelson. 1961. American wildlife and plants - a guide to wildlife food habits. Dover publications, Inc. New York.

Maycock, P.F., A.A. Reznicek and D. Gregory. 1978. Flora of Pt. Pelee National Park, Essex Co., Ontario, Erindale College, Univ. of Toronto, unpub. ms $149 \mathrm{pp}$.

McAtee, W.L. 1939. Wildfowl food plants. Collegiate Press, Ames, Iowa. $141 \mathrm{pp}$.

Mccullough, G.B. 1981. Wetland losses in Lake St. Clair and Lake ontario pp. 81-89. In A. Champagne ed.. Proceedings of the Ontario wetlands Conference. Federation of Ontario Naturalists, Don Mills, Ontario.

Moyle, J.B. and N. Hotchkiss. 1945. The aquatic and marsh vegetation of Minnesota and its value to Waterfowl. Minnesota Fisheries Research Laboratory. Tech. Bull. no. 3: 122 pp.

Papilionis, A.P. 1977. A study of Big Island, Hay Bay and Rideau Marsh in relation to marsh management. Ministry of Natural Resources, Napanee District.

Pringle, J.S. 1969. Checklist of the spontaneous vascular flora of the Royal Botanical Gardens, Hamilton, Ontario. Royal Botanical Gardens, Tech. Bull. no. 4: 46 pp.

Riley, J.L. 1978. Guide to the vascular plants and wildlife of the Rouge River valley. Ontario Field Biologist, special publication no. 1: 53pp.

Riley, J.L., S. Varga and M.J. Oldham. 1981. Additions and changes to the checklist of vascular plants of the Rouge River valley in metropolitan Toronto and Durham region. Ont. Field. Biol. 35(1): 25-35.

Savino, J.F. and R.A. Steín. 1982. Predator-prey interaction between largemouth Bass and Bluegills as influenced by simulated submersed vegetation. Trans. Am. Fish. Soc., 111: 255-266.

simser, W.L. 1982. Changes in the aquatic biota of Cootes Paradise Marsh. Tech. Bull. No. 2, Royal Botanical Gardens, Hamilton, Ontario.

soper, J.H. 1955. Some families of restricted range in the Carolinian flora of Canada. Trans. Roy. Can. Inst.. 31: 69-90.

soper, J.H. 1962. Some genera of restricted range in the Carolinian flora oc Canada. Trans. Roy. Can. Inst. 34(1): 1-56.

Tovell, W.M. 1979. The Great Lakes; geology at work. Journal of Soil and water Conservation, 34(2): 65-67.

Weller, M.W. 1978. Management of Freshwater marshes for wildlife. in R.E. Good, D.F.Whigham and R.L. Simpson, eds. Freshwater wetlands Ecological processes and Management Potential.

Werner, E.E. D.J. Hall, D.R. Laughlin, D.J. Wagner, L.A. Wilsman, and F.C. Funk. 1977. Habitat partitioning in a freshwater fish community. J. Fish. Res. Board Can., 34: 360-370. 
Table 1. Sumary of Vegetation Types

A. Wooded areas

1. Red Oak dominated

2. Sugar Maple dominated

3. Eastern Hemlock, Eastern White Pine

4. White Cedar

5. Disturbed second growth woods with some Manitoba Maple

6. Pine Plantation

B. Thickets

1. Speckled Alder sometimes with winterberry and Chokeberry

2. Hawthorns, sometimes with Dogwoods and Nannyberry

C. Open herbaceous vegetation on dry and mesic sites

1. Pasture and meadow

2. Open disturbed ground (edges of roads, railway, quarries, etc.)

3. Open granite bald

D. Marsh Vegetation

1. Sedge and graminoid marsh

1. Wet meadow-Bluejoint-sedges

2. Sedge Marsh

3. Spike-rush marsh

4. Deep Sedge marsh

2. Cattail Marsh

E. Aquatic Vegetation 
Table 2. Numbers of specles in varlous groups of aquatics in 6 Great Lakes Marshes in southern Ontario

1. Cattalls (Typha spp.)

2. Bur-reeds (sparganium spp.)

3. Pondweeds (Potamogeton spp.)

4. Nalads (Najas spp.)

5. Horned Pondweed (2. palustris)

6. Vater-plantains (Al1sma spp.)

7. Arrowheads (Sag1ttaria spp.)

8. Frog's bit family (Hydrocharitaceae)

9. Uild Rice (zizania)

10. P1ckerel-weed family (Pontederlaceae)

11. Lizard's Tall (Saururus cernuus)

12. Duckweeds (Lemnaceae)

13. Arums (Araceae)

14. Coonta1l (Ceratophyllum demersum)

15. Vater-1111es (Nymphaeaceae)

16. Aquat1c Buttercups (Ranunculaceae)

17. Vatercress (Nasturtium officinale)

18. Marsh Cinquefoll ( $P$. palustr1s)

19. Vater-milfolls (Myrlophyllum spp.)

20. Aquatic Speedwells (Veronica spp.)

21. Bladderworts (Utr1cularla spp.)

22. vater villow (Justic1a americana)

23. Hater Marigold (B1dens beck11)

$\begin{array}{ll}\text { Cataragu1 } & \text { Pelee } \\ \text { Marsh1 } & \text { Marsh }\end{array}$

$\begin{array}{rr}3 & 1 \\ 2 & 2 \\ 12 & 12 \\ 2 & 3 \\ 1 & 0 \\ 2 & 1 \\ 3 & 1 \\ 3 & 3 \\ 1 & 1 \\ 2 & 2 \\ 0 & 1 \\ 5 & 5 \\ 1 & 0 \\ 1 & 1 \\ 2 & 4 \\ 1 & 0 \\ 1 & 0 \\ 1 & 1 \\ 2 & 2 \\ 1 & 0 \\ 4 & 1 \\ 0 & 1 \\ 1 & 1 \\ & \\ 51 & 46\end{array}$

Totals

St. Clair
Marsh

Cootes
Paradise
Marsh
Marsh4

3
3
8
1
1
1
2
2
1
0
0
5
1
1
3
1
1
1
1
$?$
0
0
0

39
Rouge River Marsh 5

shawa

Second Marsh 6

2

1

2

0

0

1

1

0

$$
0
$$$$
0
$$$$
2
$$$$
1
$$$$
2
$$$$
2
$$$$
1
$$$$
1
$$$$
0
$$$$
0
$$$$
0
$$

1. Catl1ng, present study 1983

2. Maycock, Reznlcek and Gregory 1978

3. Gow, Kelly and Mclean, 1982

4. Pringle, 1969

5. R1ley, 1978

R1ley, Varga and Oldham, 1981

6. Cecile, 1981 
Table 3. Significant species in the Cataraqui Marsh study area, with habitat and status information, and UTM reference. Taxa considered rare in Canada are preceded by a "C", those rare in Ontario by an "O", those uncommon in Ontario by a "U", those rare in the central kingston region by an "R".

U Alisma gramineum L.

About 50 plants at three points along east shore in shallow water over limestone pavement (834023, 828012, 829013).

R Amphicarpa bracteata (L.) Fern. var. comosa (L.) Fern.

Edges of Typha marsh. Status in the area uncertain (844043).

R Anemone quinquefolia L.

Under Red Oak on islands in the marsh. Approximately 200 plants (845040, 848037).

R Aster ericoldes L.

Several clumps in open meadow with Agropyron repens, Agrostis stolonifera on east shore above Bells Island (818008).

U Bidens beckil Torr.

In water $1-2 \mathrm{~m}$ deep with Myrlophyllum exalbescens. At last 110 plants seen $(836034,837034)$.

U,R Carex amphibola steudel var. turgida Fern.

Distrubed deciduous woods (831007).

o Carex artitecta Mack. (c. nigromarginata var. muhlenbergit).

In dry more or less open oak woods with Danthonia splcata. Approximately 30 plants seen $(845040,846039)$.

R Carex brevior (Dewey) Mack.

In wet meadow with carex stricta. At least 10 clumps seen, possibly more common in the study area ( 848043 ).

R Carex pralrea Dewey

In wet meadow, status uncertain in the study area due to confusion in the field with $C$. diandra (848043).

o Cinna arundinacea L.

Moist Red Ash stand. Three clumps (850039).

- Crataegus brainerd11 Sarg.

At least two plants along the railway south of hwy. 401.

R Cyperus rivularis Kunth

Sandy beach. Four plants (827005).

R Dentaria X maxima Nutt.

With Erythrontum amerlcanum in Sugar Maple Woods (838029).

U Dryopteris goldiana (Hook.) Gray

with Dryopteris marginalis and Impatiens pallida on wooded

limestone talus. About 50 plants along $100 \mathrm{~m}$ of talus (851039). 
R Epilobium glandulosum Lehm.

With Calamagrostis canadensis in the marsh. Status in the study area uncertain (845040).

R Hierochloe odorata (L.) Beauv.

Open bank of rallway. Only one small patch (825034).

R Impatiens pallida Nutt.

Wooded limestone talus. Several hundred plants along $175 \mathrm{~m}$ of talus scope (851039).

C,O Jeffersonia diphylla (L.) Pers.

Limestone talus slope under Sugar Maples. Approximately 25 plants

$(825034,823031)$.

$C, O, R$ Juncus secundus Beauv.

Open granite ridge top with Polytrichum mosses and Deschampsia

flexuosa. Five small clumps (844046).

$U, R$ Juncus vasey 1 Engelm.

Open granite ridge top with Polytrichum mosses. Three clumps (844046).

R Leersia virginica Willd.

Low area in young Sugar Maple Woods. One patch about $3 \mathrm{~m}$ square (836024).

U, R Najas guadalupensis (Spreng.) Magnus

With Vallisneria americana in water $1.5-2 \mathrm{~m}$ deep in the upper

Cataraqui River (844044, 839035).

$C, O, R$, Quercus muhlenbergit Engelm.

Four mature trees in open Red Oak woods on east limestone outcrop south of hwy. 401 (824033).

U,R Utricularia gibba L.

In muddy substrate on edge of Typha marsh. Ten plants seen, possibly more common in the study area (828030).

R Utricularia minor L.

In Typha marsh. Approximately 40 plants seen $(825025,826024)$.

R Zannichellia palustris L.

washed ashore, precise origin uncertain (826005).

R Solidago hispida Muhl.

Open woods on west granite ridge. Thirty-three flowering plants seen (847048). 
Figure 1. Major features of the study area.

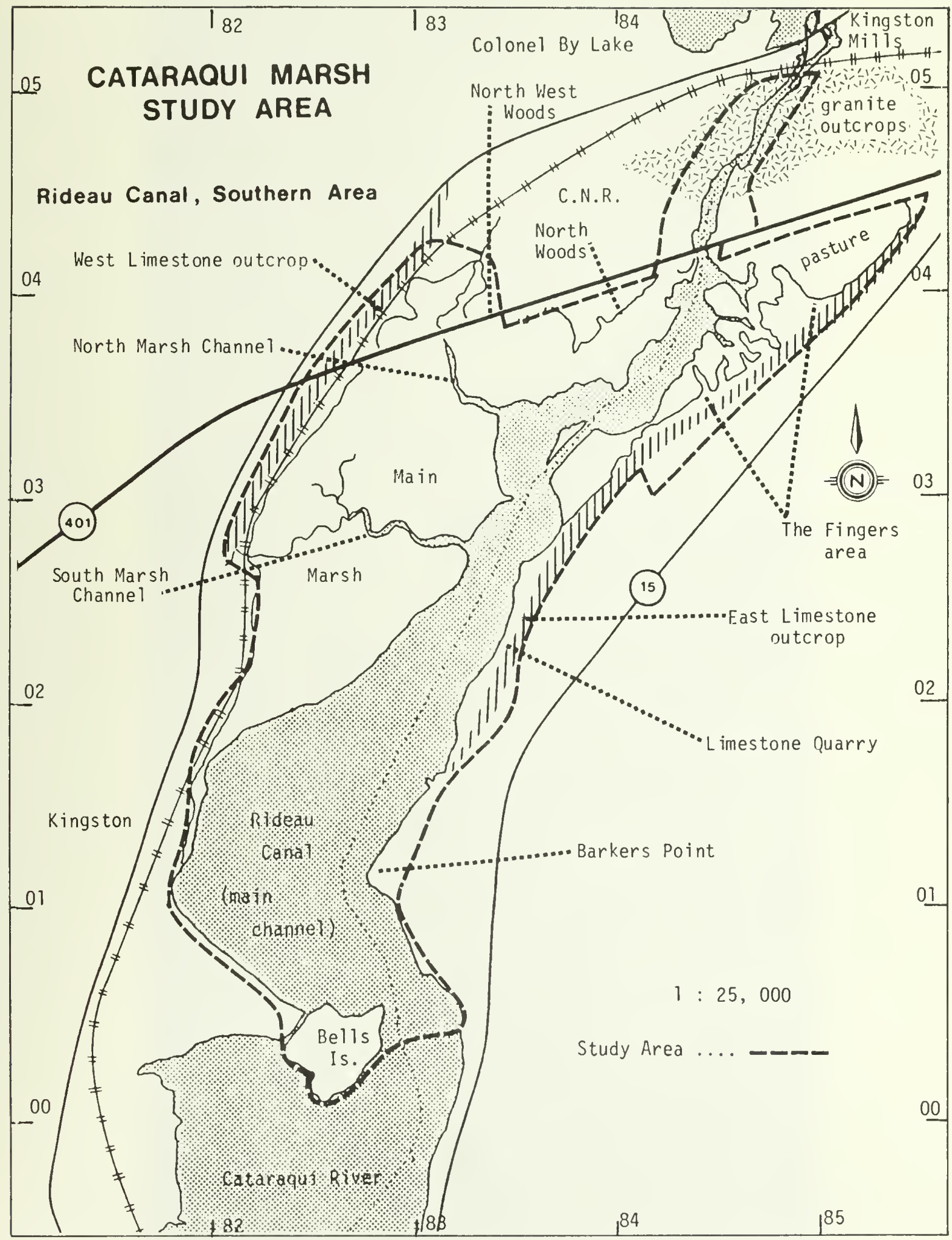


Figure 2. Aerial photograph of the study area.

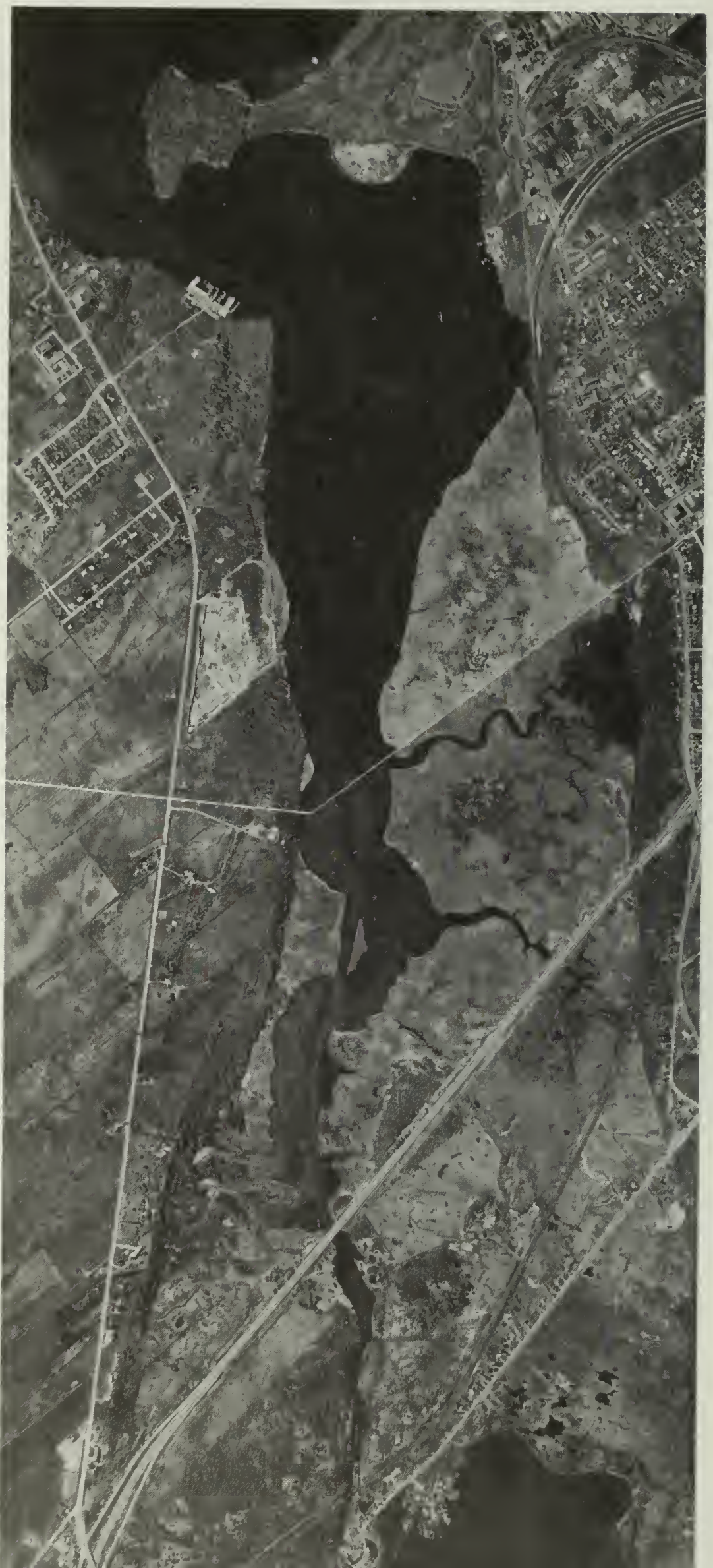


Figure 3. Locations of wooded areas (A).

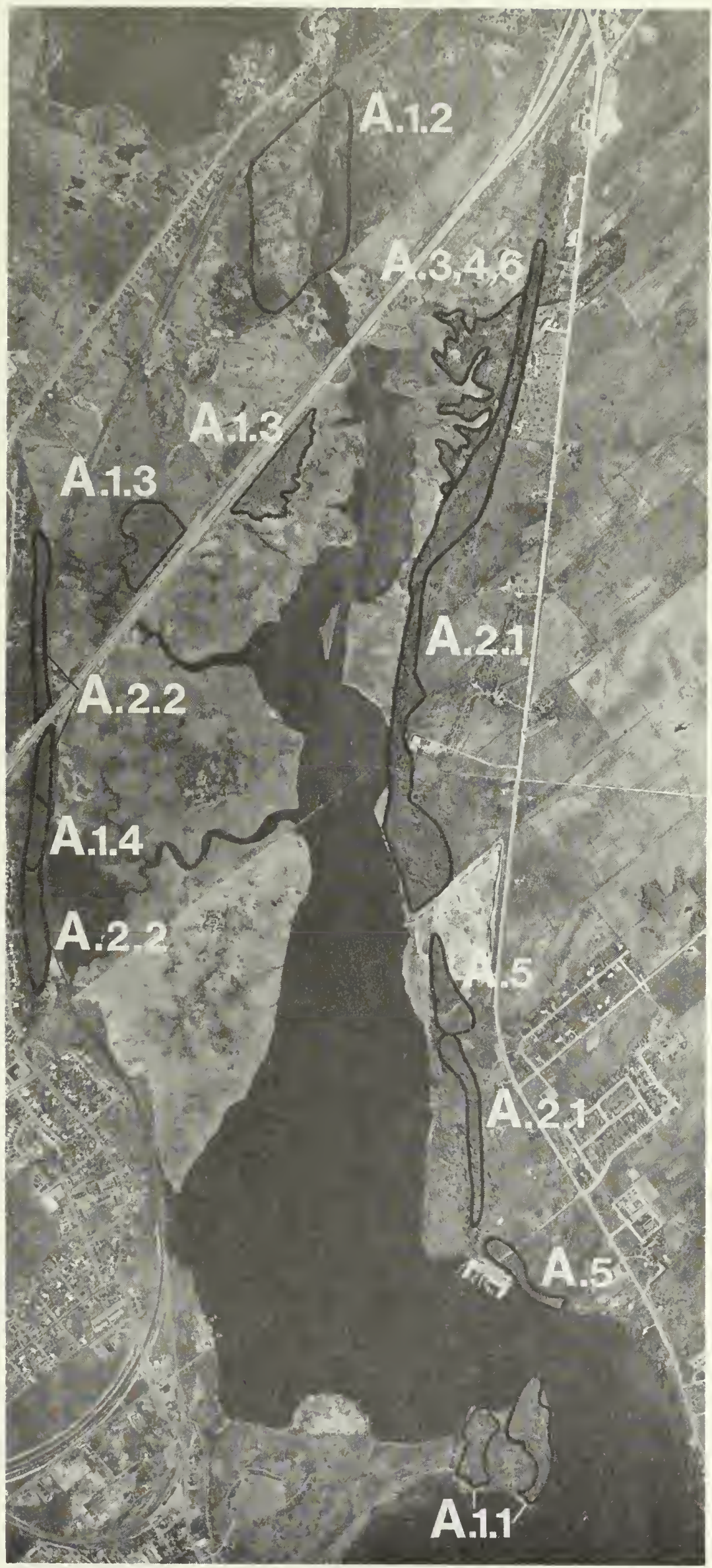


Figure 4. Location of islands and promontories.

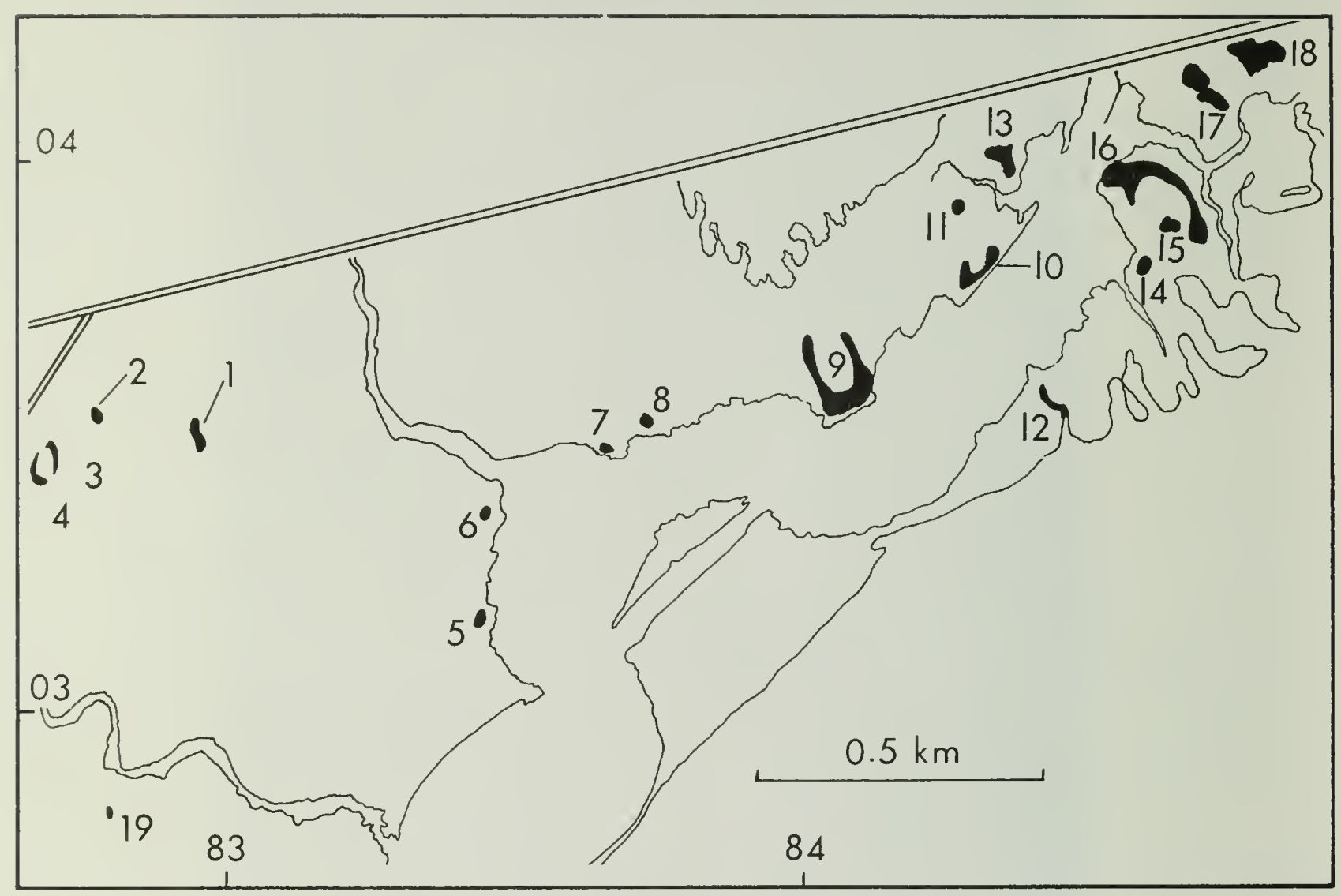


Figure 5. Locations of major areas of thickets (B) and open herbaceous vegetation on dry and mesic sites (C).

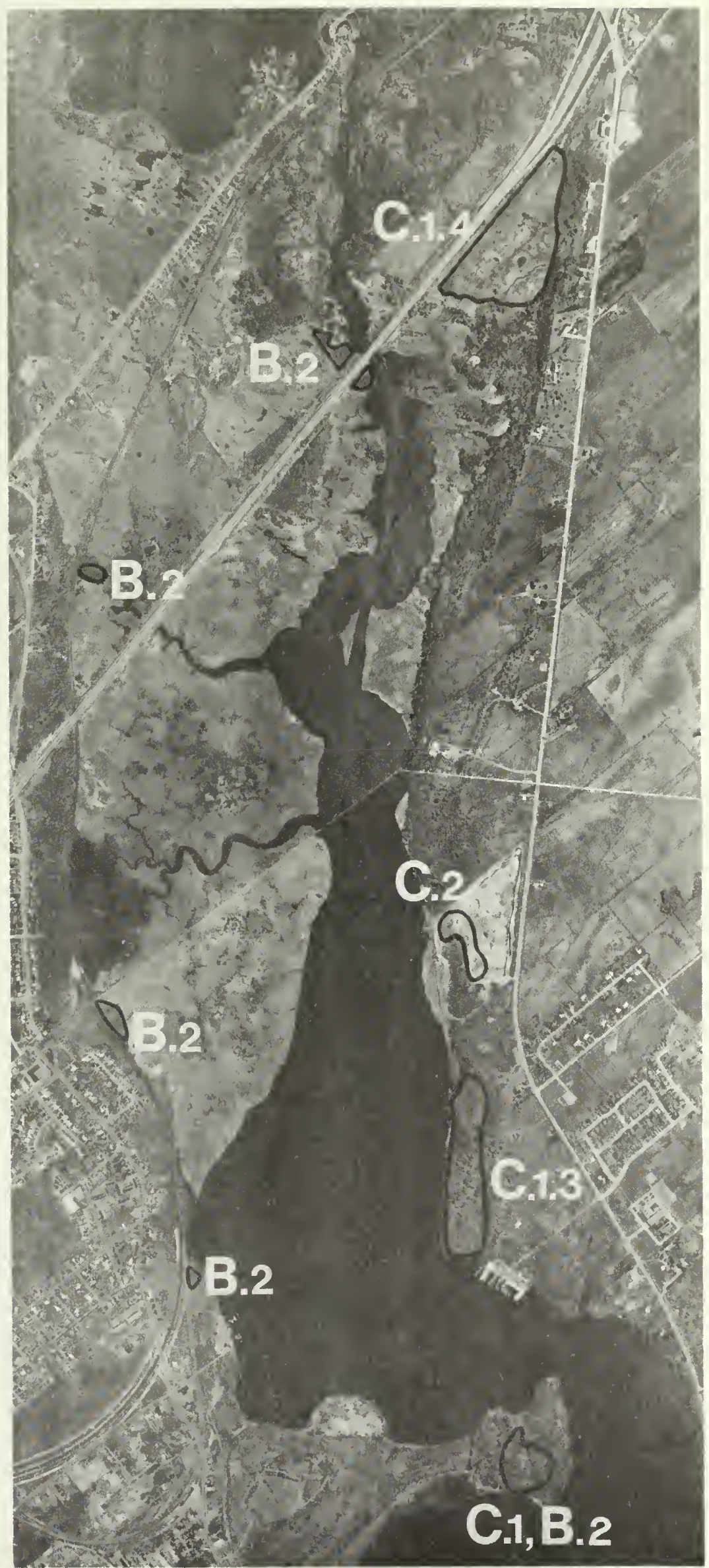


Figure 6. Locations of marsh vegetation (D).

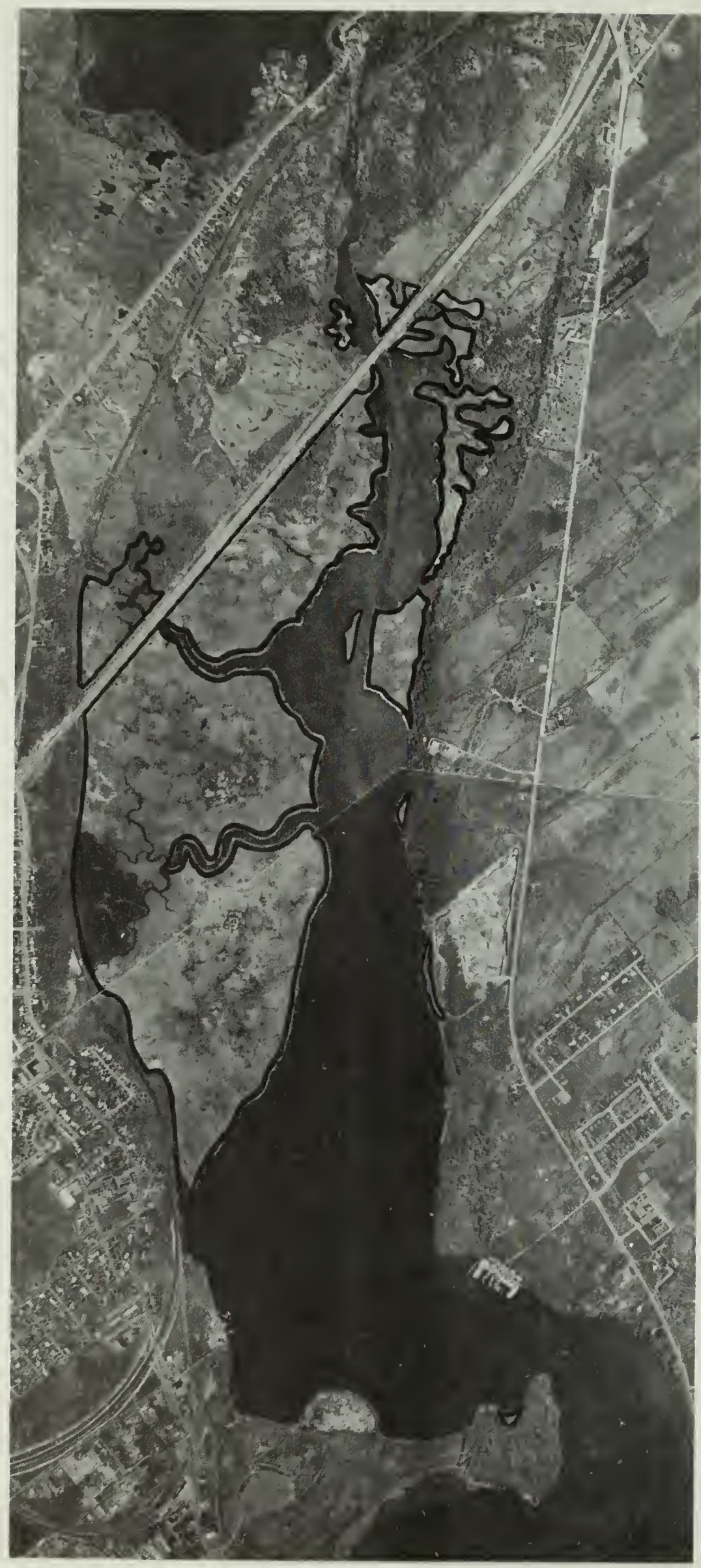


Figure 7. Distribution of Quercus muhlenberg11 (Chestnut Oak) in Ontario (above) and North America (below). The Cataraqui Marsh area is shown with a triangle. The upper map is based on herbarium specimens (dots). The lower outline map is based on Fox and soper (1954) and Little (1971).
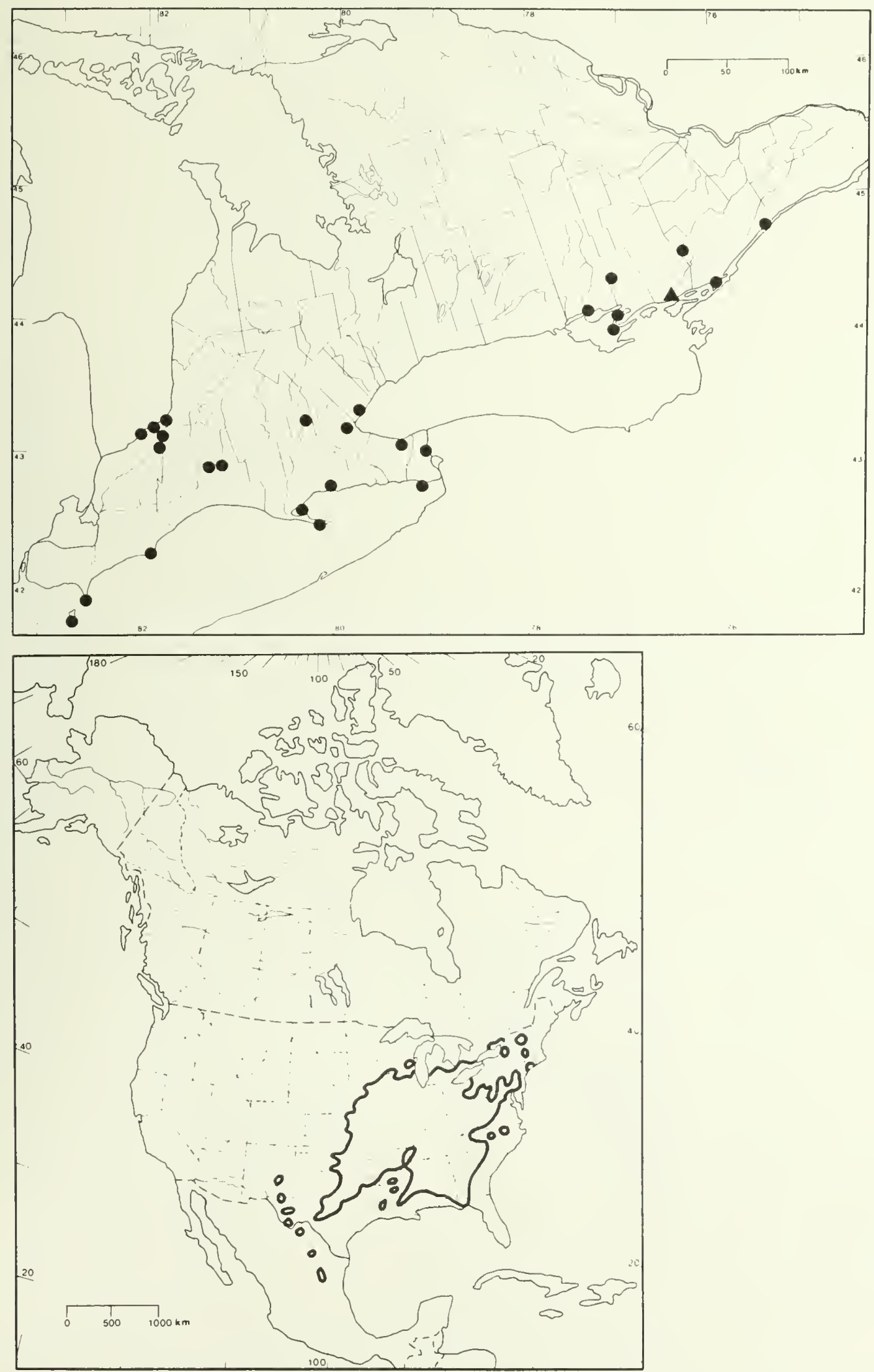
Figure 8. Distribution of Juncus secundus (One-side Rush) in Ontario (above) and North America (below). The Cataraqui Marsh area is shown with a triangle. The upper map is based on herbarium specimens (dots). The lower outline map is based on information gathered for the 4 th edition of the atlas of the rare vascular plants of Ontario.
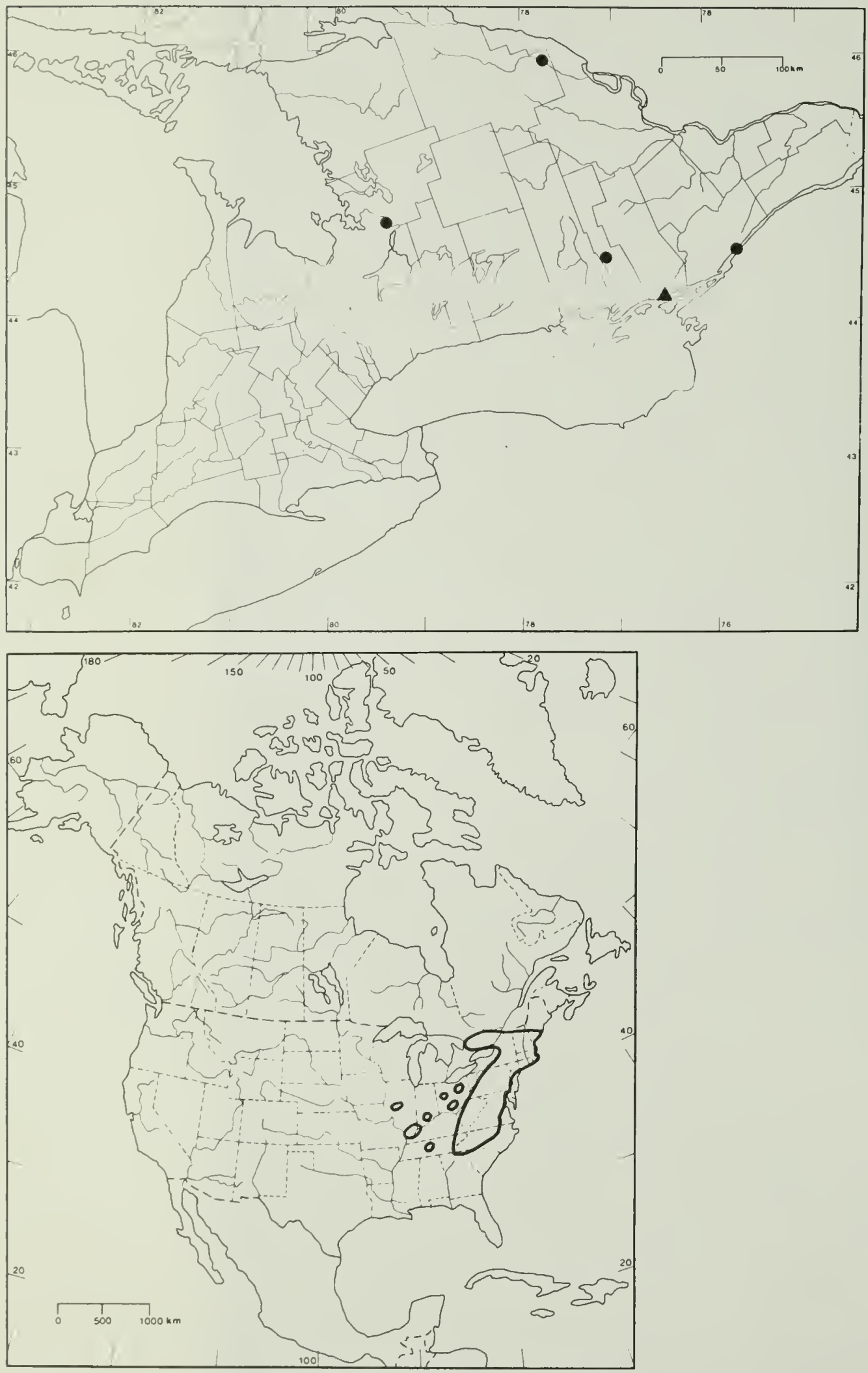
Figure 9. Distribution of Alisma gramineum (Grass-leaved Water-plantain) in Ontario (above) and North America (below). The Cataraqui Marsh area is shown with a triangle. Both maps are based on herbarium specimens.
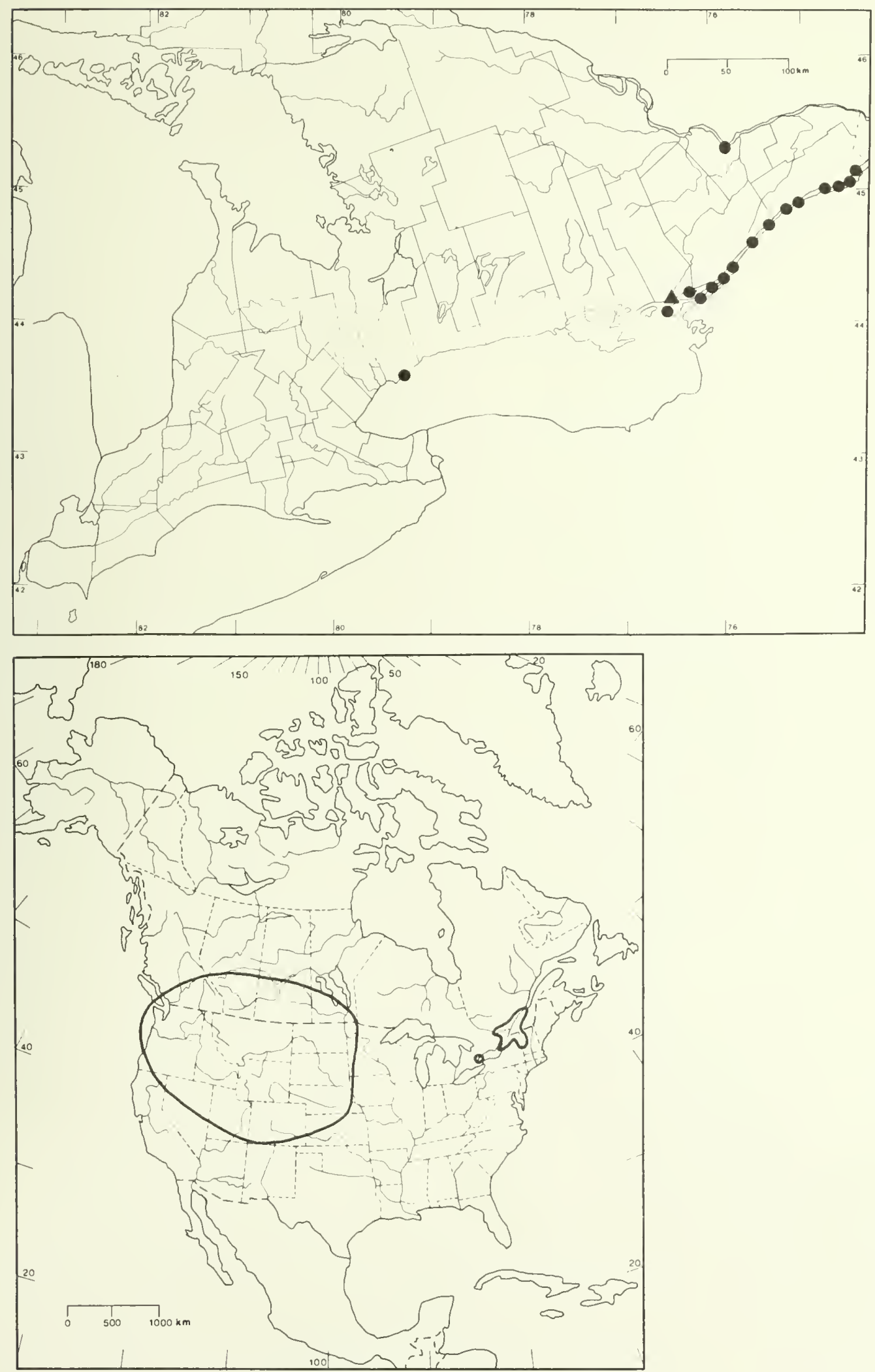




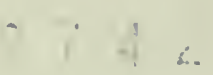

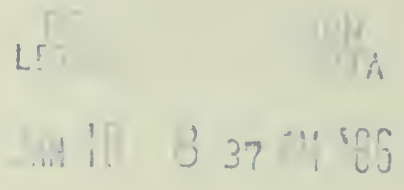

